\title{
Rezolucje interpretacyjne Rady Nieustającej ${ }^{1}$
}

W roku 1776 Sejm Rzeczypospolitej uchwalił konstytucję nadającą Radzie Nieustającej kompetencję do thumaczenia obowiązującego prawa ${ }^{2}$. Decyzja ta była tyle nowatorska, ile kontrowersyjna. Już rok wcześniej przyjęta ustawa, przyznająca Radzie szereg uprawnień o charakterze wykonawczym, zakazywała jej, pod groźbą poważnych sankcji wobec konsyliarzy, wkraczania w obszar zarezerwowany dla władzy ustawodawczej i sądowniczej ${ }^{3}$, ale opozycja parlamentarna ostro sprzeciwiała się nowemu rozwiązaniu ${ }^{4}$. W poszerzeniu praw Rady Nieustającej, oponenci reformy widzieli poważne zagrożenie zarówno

${ }^{1}$ Podstawą źródłową badań nad orzecznictwem Rady były wydane w XVIII w. Zbiory rezolucji Rady Nieustającej, obejmujące starannie wyselekcjonowane, uchwalone w latach 1776-1786, rezolucje dotyczące interpretacji prawa. Ukazały się one nakładem warszawskiej Drukarni Korpusu Kadetów Piotra Dufour w pięciu tomach w latach 1780-1788.

${ }^{2}$ Doświadczyliśmy [my król - M. G.] z niematym powagi rządowej poniżeniem: że dla nieograniczonej wolności każdego thumaczenia sobie i naciagania do swojej myśli prawa, rezolucje napominalne i rekwizycjonalne listy nasze, lubo na fundamencie jego i z okoliczności wypadle nie tylko bezskutecznemi zostawaty, lecz w zgorszenie, a przez to po prowincjach niechęć do tejże Rady ksztaltnie wprowadzać, więc żeby na przyszły czas nic podobnego trafić się nie mogło, i ta najwyższa po sejmującej z nami Rzplitej magistratura, na czele swoim Majestat Królewski zawsze majaca, czczq i bezskuteczna $w$ czynnościach swoich nie zostawała (...) jeżeliby którakolwiek jurysdykcja, lub ktożkolwiek niepostuszeństwo czynić, albo pretekstem obojętności prawa, tlumaczyć je ważyt się, Rada Nasza Nieustająca zwierzchna nad innemi jurysdykcjami będąc, takowych thumaczeń nie dozwolić, one rezolwować, et vim legis executivam mająca, do skutku prawa przywodzić ma, i powinna będzie, Volumina Legum [dalej VL] VIII, f. 850.

${ }^{3}$ Nie majac najmniejszej mocy prawodawczej, ani sadzacej, [Rada - M. G.] ma moc nakazywać tam, gdzie będzie z prawa należało; Gdyby Rada przestapiła granice swojej władzy, osoby radne sądzone będa na Sejmie przez Sady Sejmowe, VL VIII, f. 98-99.

${ }^{4}$ Marszałek wielki koronny Stanisław Lubomirski na sesji z dnia 6 września 1776 r. ostrzegał: Wlać na kogo tlumaczenie prawa, jest mu dozwolić moca tlumaczenia móc wszystkie dowoli przeistaczać prawa (...) bliski krok od tlumaczenia prawa do stanowienia onego, cyt. za R. Łaszewski, Sejm polski w latach 1764-1793, Warszawa-Poznań 1973, s. 16. Wtórował mu podczas tych samych obrad poseł podlaski - Markowski: Pozwalać bowiem tlumaczenia praw ogólnych, tlumaczenia praw ministrom shuzacych, jest to jedno, co wszystkie prawa, wszystkie stany oddać w moc Consilio Permanenti. Jest to jedno, co Sejm zrobić sejmikiem, a Radę Nieustająca Sejmem, cyt. za W. Konopczyński, Geneza i ustanowienie Rady Nieustajacej, Kraków 1917, s. 349. 
dla prerogatyw sejmu, obawiając się, że pozwoli to Radzie w sposób dowolny interpretować, a nawet poprawiać prawo stanowione, jak i niezależności sądów, których wyroki poddawane byłyby kontroli nowej instytucji ${ }^{5}$. I choć w doktrynie pojawiły się głosy popierające reformę ${ }^{6}$, w kolejnych latach szlachta podejmowała liczne próby zmierzające do odebrania Radzie nowego uprawnienia ${ }^{7}$. Mimo to przez 12 lat Rada skutecznie realizowała swoje zadanie.

Decyzje dotyczące wykładni niejasnych, niezrozumiałych przepisów wydawane były w formie rezolucji. Procedura ich przygotowania i uchwalania została szczegółowo uregulowana w specjalnej ordynacji Rady z 1776 r. ${ }^{8}$ Zgodnie $\mathrm{z}$ jej postanowieniami, zapytania i wnioski dotyczące thumaczenia prawa należało kierować na piśmie do Kancelarii Generalnej Rady, skąd przekazywano je, według kompetencji, do Departamentu Sprawiedliwości. Czynność tę odnotowywano w tzw. protokole potocznym Rady9 , co pozwalało w dalszej kolejności monitorować bieg sprawy, a w razie potrzeby egzekwować za nią odpowiedzialność. Następnie, sekretarz departamentu zobowiąza-

${ }^{5}$ Swoje obawy, przed chaosem, do którego miała doprowadzić reforma przedstawił także Stanisław Staszic: Proszę mi tu rozsądnie potrafić odpowiedzieć: kogo obywatel i sędzia ma słuchać? Jeżeli rezolucji $w$ Radzie wydanych, a czymże będa sejmy? Jeżeli praw na sejmach napisanych, a czymże będzie Rada? Oto wedlug potrzeb osobistych jedni będa stuchać rezolucji Rady, drudzy praw sejmowych; z czasem tak uroczyście upoważniona wątpliwość o prawie stworzy pogarde jego $i$ znowu nierząd. Ten byt zamyst naszych nieprzyjaciót $w$ nadaniu tlumaczenia praw Radzie, która nas, powtarzam, od nierzadu wyratować mogła, S. Staszic, Uwagi nad życiem Jana Zamoyskiego, Kraków 1926, s. 67.

${ }^{6}$ Stanowisko popierające nadanie Radzie uprawnienia do thumaczenia prawa zajął Wincenty Skrzetuski, wyjaśniając: Nie masz niebezpieczeństwa, ażeby Rada albo prawo kiedy stanowiła, albo ucisnęla swoim wyrokiem którego obywatela: bo i owszem zawsze rezolucja swoje jasnymi prawami wspiera, a nie znajdując nic o prawach czymby przyniesiona watpliwość objaśnić mogła, gotuje projekt na Sejm i Stanom Rzeczypospolitej wskazuje potrzebę ustanowienia prawa na przypadek, którego dawniejsi Prawodawcy nie przejrzeli, W. Skrzetuski, Prawo polityczne narodu polskiego, t. II, Warszawa 1787, s. 469.

${ }^{7}$ Swoje żądania ograniczenia władzy Rady, przez pozbawienie jej prawa interpretacji ustaw (przy równoczesnej jej akceptacji jako władzy wykonawczej) złożył w programie sejmikowym roku 1778 czołowy opozycjonista - Szczęsny Czacki. Podobny postulat składał starosta oświęcimski P. Małachowski, zarzucając nowej magistraturze mieszania się w sprawy sądowe. Aż w siedmiu instrukcjach sejmikowych tego roku znalazły się żądania odebrania jej prawa do wykładni ustaw, jak np. dezyderat ziemi dobrzyńskiej, aby Rada od wszelkiej legislacji wstrzymana została,W. Filipczak, Sejm 1778 roku, Warszawa 2000, s. 114 i n. Także w latach późniejszych problematyka ta budziła kontrowersje. Jeszcze w roku 1786 podejmowano próby ograniczenia czasu stosowania rezolucji tylko do okresów pomiędzy sejmami, a te z rezolucji, które nie zyskały zatwierdzenia przez sejm miały tracić ostatecznie swoje znaczenie. Dążono także do wydania Radzie zakazu zwracania się do niej z prywatnymi prośbami o interpretacje przepisów, A. Stroynowski, Opozycja sejmowa w dobie rządów Rady Nieustającej, Łódź 2005, s. 355.

${ }^{8}$ Ordynacja w Radzie Nieustającej, AGAD, tzw. Metryka Litewska [ML] VII, 76, k. 27-35.

${ }^{9} \mathrm{~W}$ Radzie Nieustającej prowadzono ścisłą archiwizację. Kancelaria Generalna Rady prowadziła dwa rodzaje protokołów: tzw. protokoły potoczne, w których rejestrowano wszystkie czynności na posiedzeniach plenarnych Rady oraz tzw. protokoły ekspedycji publicznych zawierające kopie wszystkich wychodzących z Rady pism. 
ny był ,z nich [memoriałów - M. G.] istotę rzeczy wypisać i na wierzchu memoriału oneż konotować" ${ }^{10}$. Tak przygotowany dokument przedkładany był pod rezolucję konsyliarzy wchodzących w skład Departamentu Sprawiedliwości. Na sesji departamentowej w przewidzianym ustawą co najmniej trzyosobowym gronie ${ }^{11}$, uchwałą podjętą większością głosów, wydawano opinię prawną. Asystujący w obradach sekretarz departamentu zapisywał główne postanowienia do manuału, a stamtąd przepisywał je do protokołu ${ }^{12}$. Również do niego należało zadanie przygotowania projektu rezolucji. Po zredagowaniu tekstu, na sesji departamentu sekretarz przedkładał go do aprobaty lub poprawy członkom departamentu ${ }^{13}$.

Tak sporządzony i zaakceptowany w Departamencie Sprawiedliwości projekt rezolucji był przez prezesa tegoż departamentu przedstawiany na sesjach plenarnych Rady. Po zapoznaniu się z treścią projektu i po ewentualnym wprowadzeniu poprawek lub uzupełnień, uchwalano ostateczną wersję orzeczenia.

Następnie rezolucję z podpisem króla, pierwszego senatora i marszałka Rady wysyłano do wnioskodawcy bądź strony zainteresowanej. Równocześnie jej treść, pod właściwym numerem porządkowym, wpisywana była do protokołu ekspedycji publicznych Rady Nieustającej.

Dodać należy, że tak uchwalone rezolucje mogły zostać w szczególnym trybie uchylone. W przypadkach zarzutów o błędną interpretacją prawa, a w szczególności, o przekroczenie przez Radę swoich kompetencji, zakwestionowane rezolucje trafiały pod ocenę Stanów Zgromadzonych. Tryb taki przewidywała konstytucja sejmowa pt. Objaśnienie ustanowienia Rady Nieustajacej (1776), stanowiąc:

„A wczymby jakiekolwiek osoby przestępstwo prawa postrzegły i uciśnienia siebie lub kogożkolwiek przez Radę Nieustającą doświadczyły; na każdy następujący Sejm o to wszystko zaskarżenie na Radę zanieść mogą przez przełożenie na piśmie nam i z nami sejmującej Rzeczypospolitej tego wszystkiego, w czym Rada przy boku naszym granice władzy i mocy swojej przestąpiła; które to zażalenie, tak o rezolucje, listy napominalne i rekwizycjonalne Rady Nieustającej, jako i o tłumaczenie praw przez tęż Radę inter materias pluralitate ad decidendum na Sejmach subjectas policzone być mają"14.

${ }^{10}$ AGAD, tzw. ML, 76, k. 32 v.

11 Do traktowania interesów w Departamentach, przytomność trzech osób będzie dostateczna, VL VIII, f. 93.

${ }^{12}$ Każdy Sekretarz w swoim Departamencie (...) wypadle rezolucje pluralitate do manuahu, $z$ manualu w protokót porzadnie wpisywać i też protokoły jak najporządniej utrzymywać powinien każdy w swoim Departamencie, Ordynacja, AGAD, tzw. ML, 76, k. 32 v.

${ }^{13}$ Projektów pisanie do rezolucji departamentowych należeć będzie do IMci PP. Sekretarzy, które in extenso na sesjach dla poprawy albo aprobaty Departamentom podawać maja, Ordynacja, AGAD, tzw. ML, 76, k. 32 v.

${ }^{14} V L$ VIII, f. 850. Ustalenie szczegółowego trybu zaskarżania rezolucji Rady Nieustającej poprzedzone było długotrwałą dyskusją, w trakcie której rozpatrywano trzy sposoby postępowania. 
W większości przypadków opozycja na siłę szukała przeciwnych prawu rezolucji, dotyczących zresztą spraw drobnych, co prawie zawsze skutkowało uchyleniem kilku z nich ${ }^{15}$. W latach 1776-1786 liczba takich orzeczeń wyniosła 23 lub $25^{16}$, z czego połowa przypadła na pierwszy sejm 1778 r. Znamienny okazał się natomiast rok 1782, gdy nie powiódł się wielki atak na Radę i nie uchylono żadnej rezolucji ${ }^{17}$.

Jak już wyżej wspomniano, rezolucje dotyczące interpretacji prawa wydawane były na pisemny wniosek ${ }^{18}$, który należało przesłać do Kancelarii Generalnej Rady Nieustającej. Żaden przepis nie precyzował jednak, komu przysługiwać miała legitymacja do jego złożenia ${ }^{19}$. Tymczasem, jak pokazała praktyka, katalog podmiotów składających tego rodzaju wnioski był bardzo szeroki ${ }^{20}$.

Pierwszy zakładał zasadę generalnego uchylania wszystkich rezolucji, które mogły być uchwalone przez sejm w formie konstytucji. Drugi przewidywał poddanie wszystkich decyzji Rady ocenie sejmu. Zgodnie z trzecim trybem, orzeczenia Rady poddawane miały być kontroli wyznaczonych przez sejm deputacji, które sprawozdania i wszystkie wątpliwości miały przedstawiać izbom, co w praktyce oznaczało kasowanie przez sejm tylko niektórych rezolucji, powstałych z najbardziej oczywistym naruszeniem prawa. Ostatecznie przyjęte zostało trzecie rozwiązanie, A. Stroynowski, Opozycja sejmowa.., s. 358.

${ }^{15}$ J. Michalski, Historia Sejmu Polskiego, t. I, Warszawa 1984, s. 379.

${ }^{16} \mathrm{~W}$ roku 1778 uchylono co najmniej 11 rezolucji, zob. VL VIII, f. 949 (prawdopodobną ich liczbę - 13 podaje W. Filipczak, Sejm 1778, s. 266, według Z. Szcząski zakwestionowano 11 rezolucji, Odpowiedzialność rzadu w Polsce w latach 1775-1792, CPH, t. XXVII, z. 1, 1975, s. 78, natomiast R. Łaszewski błędnie podaje, że sejm ten uchylił 10 rezolucji, Sejm Polski..., s. 21, podobnie - W. Organiściak, Wincenty Skrzetuski o rezolucjach Rady Nieustającej, „Miscellanea Historico-Iuridica", t. IX, Białystok 2010, s. 47). Na kolejnych sejmach uchylono odpowiednio: w roku $1780-2,1782-0,1784-4,1786-6$ rezolucji.

${ }^{17}$ J. Michalski, Historia Sejmu..., t. I, s. 379.

${ }^{18}$ Pisemne wnioski z zapytaniami najczęściej przybierały formę tzw. memoriału. Zgodnie z definicją podaną w XVIII-wiecznym druku, memoriat podaje i uboższy i możniejszy obywatel, i zgromadzenia różne, do króla, do Rady lub Departamentu, okazując w nim swój interes, potrzebę, watpliwość i żadanie, które wyrażaja, cyt. za A. Czaja, Między tronem, buława a dworem petersburskim. Z dziejów Rady Nieustającej 1786-1789, Warszawa 1988, s. 386. Wielokrotnie, pytania załączano także do raportów sądowych, przesyłanych w ramach kontroli, jaką Rada Nieustająca sprawowała nad sądami krajowymi. W przypadku wniosków poszczególnych departamentów Rady oraz Komisji Skarbowych przesyłano je natomiast w formie not urzędowych.

${ }^{19}$ Brak jasnych kryteriów wskazujących krąg podmiotów uprawnionych do złożenia w Radzie wniosku, spowodował, że problematyka ta była przedmiotem sporów i żywej dyskusji prowadzonej podczas sejmu w roku 1778. Kasztelan biecki Wojciech Kluszewski postulował, aby Rada thumaczyła prawo jedynie w odpowiedzi na pytania sądów. Jeszcze dalej posunął się w swoim pomyśle poseł bielski A. Mokronowski, składając w imieniu króla projekt przewidujący, że Rada może wythumaczyć prawo tylko na żądanie, którejkolwiek w kraju jurysdykcji ultimae instantiae, Z. Szcząska, Odpowiedzialność rządu..., s. 77. Przepis zezwalający Radzie na wydawanie rezolucji zawierających wykładnię prawa wyłącznie na prośbę sądu - wyrażoną, co ważne, przed wydaniem wyroku - znalazł się zresztą w jednym z przygotowywanych wówczas projektów jej reformy. Ostatecznie jednak do planowanych w tym zakresie zmian w ustawie nie doszło. Autorzy pomysłu wprowadzenia wspomnianego ograniczenia twierdzili, nie bez podstaw jak się wydaje, że memoriały osób prywatnych fałszywie przedstawiały sporne problemy, W. Filipczak, Sejm 1778, s. 211, 219.

${ }^{20}$ Szczegółowe zestawienie podmiotów składających wnioski o interpretację prawa przedstawiono w Tabeli 1. 
Tabela 1. Wykaz podmiotów składających wnioski o interpretację prawa.

\begin{tabular}{|c|c|c|c|c|}
\hline \multicolumn{2}{|c|}{ Podmioty składające wnioski o interpretację prawa } & \multicolumn{2}{|c|}{$\begin{array}{c}\text { Liczba } \\
\text { wniosków }\end{array}$} & \multirow{2}{*}{$\begin{array}{c}\begin{array}{c}\% \\
\text { ogólu } \\
\text { wnio- } \\
\text { sków }\end{array} \\
30,1\end{array}$} \\
\hline \multirow{7}{*}{$\begin{array}{l}\text { Sądy ziemskie } \\
\text { i podkomorskie }\end{array}$} & sąd ziemski* & 86 & \multirow[t]{7}{*}{164} & \\
\hline & sędzia ziemski & 51 & & \\
\hline & podsędek ziemski & 3 & & \\
\hline & pisarz ziemski & 7 & & \\
\hline & komornik ziemski & 7 & & \\
\hline & podkomorzy ziemski & 8 & & \\
\hline & inni urzędnicy sądów ziemskich (regent, surrogator) & 2 & & \\
\hline \multirow{7}{*}{$\begin{array}{l}\text { Sądy i urzędy } \\
\text { grodzkie }\end{array}$} & sąd lub urząd grodzki & 49 & \multirow[t]{7}{*}{138} & \multirow[t]{7}{*}{25,4} \\
\hline & sędzia grodzki & 27 & & \\
\hline & burgrabia grodzki & 20 & & \\
\hline & starosta grodzki & 7 & & \\
\hline & podstarości grodzki & 13 & & \\
\hline & pisarz grodzki & 14 & & \\
\hline & $\begin{array}{l}\text { inni urzędnicy grodzcy } \\
\text { (vicesgerent, viceregent, subdelegat, susceptant) }\end{array}$ & 8 & & \\
\hline \multirow{2}{*}{$\begin{array}{l}\text { Inne sądy } \\
\text { i ich urzędnicy }\end{array}$} & Trybunał Koronny i deputaci & 6 & \multirow[t]{2}{*}{14} & \multirow[t]{2}{*}{2,6} \\
\hline & Sąd Zadworny, sądy polubowne, sąd wójtowski & 8 & & \\
\hline \multirow{4}{*}{$\begin{array}{l}\text { Urzędnicy } \\
\text { centralni }\end{array}$} & kanclerz wielki koronny & 4 & \multirow[t]{4}{*}{9} & \multirow[t]{4}{*}{1,6} \\
\hline & podkanclerz koronny & 3 & & \\
\hline & referendarz koronny & 1 & & \\
\hline & sekretarz Wielkiego Księstwa Litewskiego & 1 & & \\
\hline \multirow{4}{*}{$\begin{array}{l}\text { Departamenty } \\
\text { Rady } \\
\text { Nieustajacej }\end{array}$} & Departament Wojskowy & 22 & \multirow[t]{4}{*}{25} & \multirow[t]{4}{*}{4,6} \\
\hline & Departament Skarbu & 1 & & \\
\hline & Departament Policji & 1 & & \\
\hline & Departament Interesów Cudzoziemskich & 1 & & \\
\hline \multirow{3}{*}{$\begin{array}{l}\text { Komisje } \\
\text { centralne }\end{array}$} & Komisja Skarbowa Koronna & 7 & \multirow[t]{3}{*}{15} & \multirow[t]{3}{*}{2,7} \\
\hline & Komisja Skarbowa Litewska & 7 & & \\
\hline & Komisja Edukacji Narodowej & 1 & & \\
\hline \multirow{2}{*}{$\begin{array}{l}\text { Magistraty } \\
\text { miejskie } \\
\text { i ławnicy miej- } \\
\text { scy, komisje } \\
\text { boni ordinis }\end{array}$} & magistraty miejskie i ławnicy miejscy & 13 & \multirow[t]{2}{*}{16} & \multirow[t]{2}{*}{2,9} \\
\hline & komisje boni ordinis & 3 & & \\
\hline \multicolumn{3}{|l|}{ Inni urzędnicy } & 12 & 2,2 \\
\hline \multicolumn{3}{|l|}{ Osoby prywatne } & 151 & 27,8 \\
\hline
\end{tabular}

*W rezolucjach nie sprecyzowano, którzy konkretnie urzednicy wystosowali memoriał. 
Dotyczyło to zarówno różnego rodzaju urzędów, zwracających się do Rady Nieustającej o wykładnię przepisów w związku z rozpatrywanymi przez siebie sprawami, jak też osób prywatnych, najczęściej uczestników procesów sądowych, podczas których pojawiły się wątpliwości prawne. Szczególnie pierwszą ze wspomnianych grup cechowało dość znaczne zróżnicowanie.

Wśród najczęściej wysyłających prośby o thumaczenia prawa znalazły się sądy ziemskie i ich urzędnicy ${ }^{21}$ - przede wszystkim sędziowie, podsędkowie i pisarze, którzy na ogólną liczbę 544 rozpatrywanych przez Radę wniosków, złożyli ich łącznie 164. Podobną aktywność - 138 zapytań - wykazały urzędy i sądy grodzkie oraz działający w ich ramach funkcjonariusze - sędziowie, burgrabiowie, starostowie, podstarości grodzcy i inni. W kilkudziesięciu przypadkach wnioski zostały przesłane z Komisji Skarbowych: Koronnej i Litewskiej, pozostałych departamentów Rady Nieustającej i magistratów miejskich. Kilkanaście zapytań przedłożyli urzędnicy szczebla centralnego i lokalnego: wśród nich m.in. kanclerze, podkanclerze, referendarze koronni, wojewodowie oraz marszałkowie powiatów. Obok różnego typu urzędów i występujących w ich imieniu urzędników, znaczny odsetek nadsyłanych memoriałów był, jak wspomniano, autorstwa osób prywatnych, szukających w Radzie korzystnego dla siebie rozwiązania wątpliwości prawnych w sprawach własnych.

Jak wynika ze zgromadzonych danych, aż 55,5\% zapytań przesłano do Rady z sądów ziemskich i grodzkich bądź podkomorskich. Ich aktywność w tym zakresie trzeba przede wszystkim tłumaczyć dużą liczbą rozpatrywanych przez nie spraw, a co za tym idzie, pojawiających się wątpliwości interpretacyjnych. Ponadto, przyczyn tak wyraźnej przewagi ziemstw i grodów nad innymi podmiotami upatrywać można także w postawie samych sędziów, którzy starali się przerzucić odpowiedzialność za podejmowane decyzje na Radę Nieustającą. Jak się bowiem wydaje, działania urzędników sądowych niejednokrotnie podyktowane były chęcią uchylenia się od obowiązku rozstrzygania spraw skomplikowanych, nastręczających duże problemy interpretacyjne. Dekret oparty na rozstrzygnięciu Rady zyskiwał szczególną wagę, wzmocnioną stanowiskiem organu władzy centralnej. Sam sąd zaś, dysponując rezolucją, miał poważny argument dla uzasadnienia swojego orzeczenia. W literaturze wskazuje się jednocześnie na duży autorytet, jakim nowa instytucja cieszyła się w środowisku urzędników sądowych niższego szczebla. Jak podkreślił Aleksander Czaja, powstała ,jakaś łączność między centralnym organem władzy, jakim była Rada, a lokalnym wymiarem sprawiedliwości, iż rodziło się rozumienie jej roli i znaczenia"22. Niewykluczone więc, że także

${ }^{21}$ Każda rezolucja Rady zawierała informacje o podmiocie składającym dany wniosek. W przypadku organów sądowych informacja taka bądź to ograniczała się do wskazanie sądu - jako organu kolegialnego, bądź też, podpisanych z nazwiska, czasem także z imienia, poszczególnych sędziów lub innych urzędników sądowych.

${ }^{22}$ A. Czaja, Między tronem..., s. 221. 
element zaufania, jakim cieszyła się Rada Nieustająca w sądach niższych instancji, miał wpływ na wysoką liczbę nadsyłanych przez nie zapytań.

Równocześnie, w przeciwieństwie do sądów lokalnych, bardzo małą aktywność w relacjach z Radą wykazały sądy wyższych instancji. Odnotowane memoriały kierowane z Trybunału Koronnego i Sądu Zadwornego stanowią zaledwie niecałe $2 \%$ ogółu wszystkich zapytań. Być może, wstrzemięźliwość tych sądów w zwracaniu się o pomoc w thumaczeniu prawa była, jak sugeruje cytowany już A. Czaja, ,przejawem opozycji politycznej w stosunku do Rady Nieustającej"23. Niechęć odwoływania się do opinii Rady mogła być więc próbą podkreślenia swojej niezawisłości czy autonomii. Trudno natomiast zgodzić się w pełni ze zdaniem tego autora, który tłumacząc owo zjawisko, stwierdził, że „sądy wyższe lepiej znały przepisy prawa i że poziom wiedzy ogólnej tworzących je sędziów był wyższy niż w sądach ziemskich i grodzkich"24. Jeśli możemy przychylić się do tej tezy w odniesieniu do Sądu Zadwornego, w powszechnej opinii cechującego się dobrym przygotowaniem prawniczym i zawodowym jego członków, to trudno znaleźć dla niej uzasadnienie w przypadku sędziów trybunalskich. Deputaci, podobnie jak sędziowie ziemscy, nie byli zazwyczaj wykształceni w zakresie prawa. Ich znajomość materii dotyczyła bowiem praktyki, nie teorii. Ponadto zarówno przed, jak i po odbyciu rocznej kadencji w sądzie trybunalskim pełnili oni swoje funkcje w ziemstwach lub grodach ${ }^{25}$, poziom wiedzy prezentowanej przez sędziów Trybunału musiał być więc zbliżony do tego, jaki cechował urzędników jurysdykcji niższego szczebla.

Wnioski o interpretację prawa kierowano do Rady Nieustającej z obszaru całej Rzeczypospolitej, zarówno województw koronnych jak i litewskich. $\mathrm{Z}$ dokonanych ustaleń wynika, że same tylko zapytania sądowe pochodziły z 64 różnych ośrodków (w tym 18 leżących na Litwie). Jednocześnie, wyraźnie zarysowuje się tu liczebna przewaga wniosków napływających z prowincji koronnych, które stanowią 85\% wszystkich nadesłanych do Rady. Przyczyn takiej dysproporcji można upatrywać w niedoskonałościach prawa zwyczajowego. Prawo koronne skodyfikowane zostało bowiem w niewielkim stopniu. Na obszarze Wielkiego Księstwa Litewskiego od blisko dwóch stuleci obowiązywał natomiast III Statut - dzieło jak na swoją epokę niemal doskonałe i kompletne, którego stosowanie nie rodziło takich problemów i wątpliwości, jak poruszanie się w gąszczu norm zwyczajowych, przeplatanych nie zawsze jasno i zrozumiale napisanymi konstytucjami sejmowymi.

Jak już wspomniano, żadna $\mathrm{z}$ ustaw nie ograniczała kręgu podmiotów uprawnionych do przedkładania w Radzie zapytań odnoszących się do inter-

${ }^{23}$ Ibidem.

${ }^{24}$ Ibidem.

${ }^{25}$ W. Bednaruk, Trybunat Koronny. Szlachecki sąd najwyższy w latach 1578-1794, Lublin 2008, s. 234. 
pretacji prawa. W konstytucji z $1776 \mathrm{r}$. posłużono się jedynie ogólnym terminem „obywatel” 26 , co nie stawiało w uprzywilejowanej pozycji żadnego ze stanów społecznych. Prawo do złożenia zapytania przysługiwało więc nie tylko reprezentantom szlachty. Mimo to nie licząc kilkunastu urzędowych memoriałów przesłanych do Rady przez przedstawicieli magistratów miejskich, tylko trzy prywatne wnioski były autorstwa mieszczan ${ }^{27}$. Brak było natomiast zupełnie jakiejkolwiek aktywności ze strony sądów miejskich. Fakt ten można tłumaczyć charakterem samej Rady, która była organem szlacheckim, w skład którego wchodzili reprezentanci szlachty, wybierani przez szlachtę, działającym w państwie, gdzie władza w pełni należała do szlachty. W gronie konsyliarzy nie było przedstawicieli stanu miejskiego. Wielce prawdopodobne więc, że także w świadomości mieszczan Rada funkcjonowała jako instytucja o charakterze stanowym, realizująca w głównej mierze interes szlachty.

Problematyka poruszana w rezolucjach Rady Nieustającej obejmowała wszystkie gałęzie prawa, a katalog materii stanowiących przedmiot rozstrzygnięć konsyliarzy był bardzo szeroki ${ }^{28}$.

Przede wszystkim zwraca uwagę wysoka liczba spraw dotyczących zasad organizacji i funkcjonowania sądownictwa, którym Rada poświęciła ponad $42 \%$ swoich rezolucji ${ }^{29}$. Przesyłane zapytania najczęściej dotyczyły kompetencji poszczególnych jurysdykcji lub praw i obowiązków urzędników sądowych. Oba powyższe zagadnienia stanowiły blisko $32 \%$ wszystkich badanych przez Radę przypadków.

Przykładem takiej rezolucji jest orzeczenie wydane na wniosek urzędu grodzkiego włodzimierskiego, podnoszącego problem właściwości sądu w sprawach o fałszerstwo. Biorąc pod uwagę, z jednej strony, konstytucję z 1726 r. pt. Falsificationes actorum, nakazującą kierować takie przypadki do Trybunału, z drugiej zaś ustawę pt. Złączenie Trybunału Koronnego z 1768 r., zakazującą rozstrzygania w Trybunale spraw, nierozpatrywanych wcześniej w ziemstwie lub grodzie, urzędnicy zapytali: „w takowym przypadku sąd grodzki, czyli ma według konstytucji pierwszej sprawę takową do Trybu-

${ }^{26}$ Departament Sprawiedliwości examinować będzie wszystkie memoriały i skargi obywatelów, jako też odpowiedzi z jednej i z drugiej strony, które do Rady Nieustającej zaniesione będa, VL VIII, f. 853.

${ }^{27}$ Ustalenie tego faktu było możliwe dzięki informacjom zawartym w samych rezolucjach. Osoby stanu mieszczańskiego oznaczone były jako „Szlachetne”, w stosunku do przedstawicieli stanu szlacheckiego używano określenia „Urodzeni”.

${ }^{28}$ Szczegółowe zestawienie materii przedstawiono w Tabeli 2.

${ }^{29}$ Ustalenia te skonfrontowano z podobnymi, poczynionymi przez A. Czaję na podstawie rezolucji uchwalonych w latach 1786-1789. Pomimo pewnych różnic w przyjętych kryteriach podziału materii (oraz zdecydowanie mniejszej liczby analizowanych przez niego rezolucji-165), generalne rezultaty badań są zbliżone. Także z analizowanego przez Czaję materiału wynika, że stosunkowo duży odsetek rezolucji, choć wyraźnie mniejszy niż w niniejszym zestawieniu, poświęcono ustrojowi i funkcjonowaniu sądów (w tym sądów polubownych) - Czaja wskazał 44 takie przypadki, co stanowiło 27\% badanych przez niego rezolucji, A. Czaja, Między tronem ..., s. 221-222. 
Tabela 2. Materie poruszane w rezolucjach Rady Nieustającej

\begin{tabular}{|c|c|c|c|c|}
\hline \multicolumn{2}{|c|}{ Materie poruszane w rezolucjach Rady Nieustającej } & \multicolumn{2}{|c|}{$\begin{array}{l}\text { Liczba } \\
\text { rezolucji }\end{array}$} & \multirow{2}{*}{$\begin{array}{c}\begin{array}{c}\% \\
\text { ogółu } \\
\text { rezo- }\end{array} \\
\text { lucji }\end{array}$} \\
\hline \multirow{7}{*}{$\begin{array}{l}\text { Ustrój i działanie } \\
\text { sądów }\end{array}$} & urzędnicy sądowi - status, prawa, obowiązki & 89 & \multirow[t]{7}{*}{229} & \\
\hline & $\begin{array}{l}\text { kompetencje sądów - problematyka ustalenia wła- } \\
\text { ściwości rzeczowej i miejscowej }\end{array}$ & 85 & & \\
\hline & regestry sądowe & 23 & & \\
\hline & opłaty sądowe; przepisy o papierze stemplowanym & 13 & & \\
\hline & kadencje sądowe - terminy, proklamaty & 10 & & \\
\hline & funkcjonowanie kancelarii sądowych & 6 & & \\
\hline & palestra - prawa i obowiązki członków & 3 & & \\
\hline \multirow{12}{*}{$\begin{array}{l}\text { Prawo } \\
\text { procesowe }\end{array}$} & postępowanie egzekucyjne & 46 & \multirow[t]{12}{*}{157} & \multirow[t]{12}{*}{28,8} \\
\hline & wyrok, apelacja, wznowienie procesu & 32 & & \\
\hline & dylacje/przepisy o komunikacji dokumentów & 17 & & \\
\hline & prawa i obowiązki stron procesu & 17 & & \\
\hline & postępowanie dowodowe & 8 & & \\
\hline & proces graniczny & 7 & & \\
\hline & proces ekstradycyjny o zbiegłych poddanych & 6 & & \\
\hline & terminy procesowe & 6 & & \\
\hline & pozew & 5 & & \\
\hline & kondemnaty & 5 & & \\
\hline & koszty procesowe & 3 & & \\
\hline & inne & 5 & & \\
\hline \multirow{13}{*}{$\begin{array}{l}\text { Prawo } \\
\text { prywatne }\end{array}$} & opieka i kuratela & 21 & \multirow[t]{13}{*}{107} & \multirow[t]{13}{*}{19,7} \\
\hline & $\begin{array}{l}\text { problematyka dóbr duchownych, fundacji nowych } \\
\text { instytucji kościelnych i dziesięciny }\end{array}$ & 17 & & \\
\hline & prawo spadkowe & 13 & & \\
\hline & ochrona własności nieruchomości & 10 & & \\
\hline & umowa pożyczki, problematyka prowizji, weksle & 10 & & \\
\hline & emfiteuza & 8 & & \\
\hline & zawieranie umów, akty oświadczenia woli & 6 & & \\
\hline & zastaw & 6 & & \\
\hline & ewikcje i widerkaufy & 4 & & \\
\hline & przepisy o propinacji & 4 & & \\
\hline & zdolność do czynności prawnych & 3 & & \\
\hline & dzierżawa & 3 & & \\
\hline & przewóz rzeczny & 2 & & \\
\hline
\end{tabular}


cd. Tab. 2

\begin{tabular}{|c|c|c|c|c|}
\hline \multicolumn{2}{|c|}{ Materie poruszane w rezolucjach Rady Nieustającej } & \multicolumn{2}{|c|}{$\begin{array}{c}\text { Liczba } \\
\text { rezolucji }\end{array}$} & \multirow{2}{*}{$\begin{array}{c}\% \\
\text { ogólu } \\
\text { rezo- } \\
\text { lucji } \\
2,6 \\
\end{array}$} \\
\hline \multirow[t]{3}{*}{ Prawo karne } & prawo karne materialne & 3 & \multirow[t]{3}{*}{14} & \\
\hline & proces karny & 3 & & \\
\hline & problematyka związana z wykonywaniem kary & 8 & & \\
\hline \multirow[t]{6}{*}{ Inne } & podatki & 11 & \multirow[t]{6}{*}{37} & \multirow[t]{6}{*}{6,8} \\
\hline & $\begin{array}{l}\text { problematyka miast: funkcjonowanie komisji boni } \\
\text { ordinis, przepisy o cechach, nabór uczniów do Aka- } \\
\text { demii Lekarskiej, skład rady miejskiej, kwaterunek } \\
\text { wojsk, nabywanie przez mieszczan dóbr ziemskich } \\
\text { i inne }\end{array}$ & 10 & & \\
\hline & organizacja i funkcjonowanie sejmików ziemskich & 3 & & \\
\hline & funkcjonowanie Rady Nieustającej & 2 & & \\
\hline & nobilitacje & 2 & & \\
\hline & inne & 9 & & \\
\hline
\end{tabular}

nału odesłać, czyli podług konstytucji powtórnej tęż sprawę niedrabowaną sądzić?" Rada rozwiązała ten problem opierając się na regule lex posterior derogat legi priori i odpowiedziała, że ,wyżej wyrażone 1768 r. prawo, jako od konstytucji 1726 r. jest późniejsze, tak też i w przypadku primo intuitu przychodzącej sprawy, dla urzędu grodzkiego włodzimierskiego, prawidłem być powinno" 30 .

Precyzyjne ustalenie kompetencji sądów było także przedmiotem pytania nadesłanego przez surrogatora sądu kaliskiego o nazwisku Lipski. Powołując się na „obojętność dwóch praw”31, zwrócił się on do Rady Nieustającej z zapytaniem: ,czyli sługa odprawiony od obywatela w służbie wojskowej będącego, powinien in privata injuria w Departamencie Wojskowym poszukiwać na nim sprawiedliwości, lub też w sądzie grodzkim przyzwoitym?” Konsyliarze wytłumaczyli, że skierowanie pozwu do właściwego sądu zależy od charakteru sporu i stwierdzili, iż „każdy z obywatelów jakiejkolwiek kondycji, mający sprawę z osobą wojskową, gdy gatunek tej sprawy z służby wojskowej nie pochodzi, w sądzie cywilnym przyzwoitym, nie zaś w Departamencie Wojskowym, rzecz swoją popierać może"32.

Równie wiele wątpliwości co ustalenie rozdziału kompetencji różnego rodzaju sądów budziły kwestie statusu sędziów, subdelegatów, organizacji ich pracy itp. Za przykład posłużyć może wniosek dotyczący uprawnień pisarza

${ }^{30}$ Rezolucja nr 197 z 13.11.1781 r., Zbiór rezolucji Rady Nieustającej, Warszawa, 1785, s. 54.

${ }^{31}$ Chodziło o ustawy pt. Objaśnienie i odmiana konstytucji o Komisjach Wojskowych z 1775 r. oraz Powinności i władza departamentów w Radzie przy Boku Naszym Nieustającej z 1776 r.

${ }^{32}$ Rezolucja nr 316 z 16.04.1784 r., Zbiór rezolucji..., 1786, s. 22. 
sądowego, zgłoszony przez pisarza grodzkiego drohickiego - Wojciecha Kosińskiego, który zapytał w swoim memoriale, czy ,gdy podstarosta lub sędzia grodzki sądzący z pisarzem ma swoją sprawę i posadzi do niej na swe miejsce subdelegata, przy kim wtedy decisiva sententia, czyli przy pisarzu, czyli przy posadzonym subdelegacie?" Na co Rada Nieustająca, powołując się na konstytucję sejmową pt. Objaśnienie denegati iudicii z 1775 r. $^{33}$, wyjaśniła, że „gdy na sądzie grodzkim pisarz grodzki znajduje się przytomny, subdelegat nawet $\mathrm{w}$ sprawie drugiej osoby sądowej, miejsca nie ma, lecz tenże pisarz grodzki sądzić powinien" 34 .

Zasadom pełnienia urzędu komornika poświęcił swój memoriał - wskazany jedynie z imienia Józef, który dopraszał się od Rady Nieustającej, „aby komornik kondescensją graniczną już poczętą, a z limity na dniu dziewiątym miesiąca lipca w roku teraźniejszym przypadającą, kontynuował, bez względu na to, iż po postąpieniu podkomorzego na kasztelanię, zdaje się jego urzędowanie ustawać”. Rada nie przychyliła się do wspomnianej prośby i uznając, że proponowana przez autora wniosku interpretacja prawa jest nie do przyjęcia, oświadczyła, że „po zejściu lub postąpieniu każdego podkomorzego, urzędowanie komornika ustawać powinno"35.

Spośród innych spraw dotyczących funkcjonowania sądownictwa, ponad 4\% rezolucji poświęcono kwestii regestrów sądowych. Był to rezultat braku jasnych zasad, które winny regulować ich liczbę, rodzaj i przeznaczenie, co w następstwie skutkowało częstymi nadużyciami przy wpisywaniu spraw do tzw. regestrów uprzywilejowanych, a więc tych, które rozpatrywano w pierwszej kolejności.

Zjawisko to ilustruje sprawa przedstawiona Radzie przez wojskiego Michała Głębockiego ${ }^{36}$. Został on oskarżony przez deputata na Trybunał „Ur. P”. - o kradzież podwód z lasu i przyjęcie do swojego majątku zbiegłego chłopa. Proces wytoczony został w Trybunale Koronnym $\mathrm{z}$ regestru directi mandati, co spotykało się z ostrym sprzeciwem Głębockiego. W swoim piśmie do Rady wojski podniósł, że pozwanie go ze wspomnianego regestru było ze strony deputata niedopuszczalnym nadużyciem przepisów prawa $\mathrm{z}$ roku 1768. Jego zdaniem, w myśl konstytucji pt. Złaczenie Trybunału Koronnego, regestr directi mandati przeznaczony był: „,na sprawy violatae securitatis tribunalitiae intra moenia civitatis", a więc związane stricte z naruszeniem bezpieczeństwa osoby sędziego w obrębie miasta, w którym obradował

${ }^{33}$ Zgodnie z treścią tej konstytucji: W grodach zaś gdyby zachorowat podstarosta, tedy na miejscu jego sędzia lub pisarz sązić powinien, a in casu legalis impedimenti na tych, tedy starosta subdelegata nominować ma, którego gdyby nie nominowat, na ten czas sposobem w prawie opisanym, dla ziemstw stużącym, subdelegat do tej jednej kadencji obrany będzie, VL VIII, f. 116.

${ }^{34}$ Rezolucja nr 123 z 4.05.1781 r., Zbiór rezolucji..., 1785, s. 156.

${ }^{35}$ Rezolucja nr 228 z 24.06.1777 r., Zbiór rezolucji..., 1785, s. 125.

${ }^{36}$ Michał Głębocki h. Doliwa - wojski większy owrucki (1770-1796), Urzędnicy województw kijowskiego i czernichowskiego XV-XVIII w., red. A. Gąsiorowski, Kórnik 2002, s. 269. 
Trybunał. Przypadek wspomnianej kradzieży tej kategorii spraw z pewnością nie podlegał. Przypuszczać można, że deputat doskonale zdawał sobie sprawę z obejmującego go zakazu wnoszenia powództwa w okresie pełnienia rocznej funkcji sędziego Trybunału ${ }^{37}$. Jedynym sposobem szybkiej realizacji roszczeń było więc wszczęcie procesu ze specjalnego regestru przeznaczonego dla deputatów. Dlatego w wyjaśniającym swoje działanie piśmie do Rady, powód powołał się na konstytucję sejmową z roku 1670 pt. Sprawy deputackie w Trybunale, zapewniającą, jak sam stwierdził, „bezpieczeństwo osób i dóbr funkcją deputacką sprawujących”. Było to, w jego przekonaniu, wystarczające uzasadnianie skierowania sprawy do Trybunału w przyspieszonym trybie, $\mathrm{z}$ regestru directi mandati ${ }^{38}$. Tłumaczenie nie przekonało jednak konsyliarzy. Wszelkie obiekcje Rada rozstrzygnęła bowiem na korzyść Michała Głębockiego. Przytaczając treść przywołanej przez deputata ustawy, wyraźnie podkreśliła, że „konstytucja ta (...) upewniając dla deputatów, osób ich familii i dóbr, bezpieczeństwo, inne wszelkie sprawy tam ex actoratu quam reatu onych w Trybunale popierać zakazuje". Równocześnie konsyliarze stwierdzili, że prawo z roku 1768 „szczególnie zapewnić chce sądu sędziów trybunalskich i onym aktualnie służących intra moenia civitatis ubezpieczenie i tylko w przypadku takowego bezpieczeństwa naruszenia regestr directi mandati do prawnej egzekucji i sądzenia przeznacza i wyraźnie generalność ekskluduje; przeto o inne wiolencje lub z procederu prawnego wynikające sprawy, żadnym pretekstem do tego regestru podciągane być nie powinny, które etiam stante functione deputata in foro competenti rozsądzane być mają" ${ }^{39}$. Rada nie miała więc w tej sprawie żadnych wątpliwości, jednoznacznie potwierdzając, że sędzia trybunalski działał niezgodnie z prawem. Powyższy przypadek jest zatem jaskrawym przykładem próby nielegalnego wykorzystania przysługujących z racji pełnionego urzędu szczególnych uprawnień, do załatwienia spraw prywatnych, co dowodzi, że pełnienie tak odpowiedzialnej funkcji pu-

${ }^{37}$ Konstytucja z 1768 r. wyraźnie stanowiła, że Deputat w czasie funkcji swojej, bądź przytomny bąd́ nie, nikogo wzdawać nie ma i takowa kondemnata, gdyby otrzymana była, szkodzić nikomu nie powinna, ani in sublationem processus wchodzić, wyjąwszy sprawy ex re leasae securitatis na osobie deputata stante eius functione, w których nie stawająca stronę wzdawać deputatowi moc się udziela, VL VII, f. 699.

${ }^{38}$ Po przeprowadzonej w roku 1764 reformie w regestrze tym umieszczane być miały sprawy związane z naruszeniem bezpieczeństwa deputatów, ich rodzin i służby, W. Bednaruk, Trybunat Koronny..., s. 153. Regestr directi mandati miał tę dodatkową przewagę nad regestrem taktowym, że można go było brać w każdej chwili, nie czekając godziny szóstej popołudniu przeznaczonej dla regestru taktowego. To również sprzyjało szeregowi nadużyć. Szerzej pisze o tym zjawisku J. Michalski, Studia nad reforma sądownictwa i prawa sądowego w XVIII w., Wrocław-Warszawa 1958, s. 136-137. Warto dodać, że projekt Zbioru Praw Andrzeja Zamoyskiego przewidywał zgodnie z § 23, art. VII, cz. III, utrzymanie w Trybunale regestru spraw uczynkowych, do którego wpisywane być miały $\mathrm{m}$. in. sprawy o zgwałcenie bezpieczeństwa w osobach Trybunały składajacych lub ich ludzi, Zbiór Praw Sądowych, cz. III, s. 38, Warszawa 1778.

${ }^{39}$ Rezolucja nr 363 z 14.10.1777 r., Zbiór rezolucji..., 1785, s. 21-22. 
blicznej, jak trybunalska, nie zawsze szło w parze z godnością, bogobojnością i cnotliwością, których to cech wymagano od kandydatów na deputatów ${ }^{40}$.

Wśród pozostałych w tej kategorii spraw, dominowały głównie kwestie funkcjonowania kancelarii ziemskich i grodzkich ${ }^{41}$, stosowania przepisów o opłatach w tym o papierze stemplowanym, oraz odbywania kadencji sądowych - czasu ich trwania, odwoływania, ogłaszania ${ }^{42}$.

Blisko trzy na każde z dziesięciu wydanych przez Radę rezolucji dotyczyło zagadnień szeroko rozumianego prawa procesowego $0^{43}$. Dominowały tu rozstrzygnięcia z zakresu postępowania egzekucyjnego $\left(8,5 \%\right.$ ogółu rezolucji $\left.{ }^{44}\right)$ - głównie zasad uczestnictwa oddziałów wojska przy prowadzeniu tradycji.

Przykładem jest tu jedna z ponad dwudziestu rezolucji, stanowiących odpowiedź na zapytanie sformułowane przez Departament Wojskowy Rady Nieustającej. Opierając się na uniwersale królewskim z 1779 r. - nakazującym, aby w przypadku wyparcia z nieruchomości, zajętej w drodze sądowej egzekucji, strony, która wygrała proces, przez niepodporządkowującą się wyrokowi tzw. stronę skonwinkowaną, zawsze przydzielano tej pierwszej pomoc wojskową do ponownego wprowadzenia w posiadanie tych dóbr - autorzy wniosku zapytali: ,czy gdy zdarzy się, iż nie ten, kto procesem był skonwinkowany, lecz kto inny w proces niewchodzący, wypiera $z$ dóbr urzędownie cum brachio militari zatradowanych, czyli w takowym przypadku, rekwirującej stronie, przez trzeciego wyrugowanej, pomoc wojskowa, sposobem jako wyżej, dodawana być powinna?" Rada nie miała żadnych wątpliwości, że bez względu na to, kto dopuszcza się aktu przemocy wobec nowego właściciela, prawo powinno zawsze stać po jego stronie i analogicznie do przypadku przedstawionego w uniwersale, prośba taka winna być spełniona. Stwierdzono więc, że „gdy ustronny najazd na dobra zajęte procesem i pod tradycją zostające nastąpi, nie inaczej rozumiany być może, jak za zirytowanie tradycji. Zaczym wypartemu z posesji tradycyjnej przez kogożkolwiek, silniejsza pomoc ma być dodana"45.

6\% rezolucji poruszało problematykę wyroków, ich prawomocności, wzruszania, zasad składania apelacji czy wznawiania procesu z tytułu odnalezionych, nieznanych wcześniej sądowi dokumentów.

${ }^{40}$ O. Balzer, Geneza Trybunatu Koronnego, Warszawa 1886, s. 208.

${ }^{41}$ A. Czaja wyodrębnił 18 przypadków (11\%) obejmujących problematykę funkcjonowania kancelarii i organizacji regestrów sądowych, Między tronem..., s. 228. W poniższym zestawieniu rezolucji z lat 1776-1786 materie te zostały rozdzielone. W sumie odnotowano jednak 29 rezolucji regulujących oba te zagadnienia $(5,3 \%)$.

${ }^{42}$ A. Czaja wskazał 9 rezolucji regulujących te zagadnienia (5,5\%), Między tronem..., s. 222.

${ }^{43}$ Wyniki te niemal idealnie pokrywają się z ustaleniami A. Czai, który wskazał 47 przypadków $(28 \%)$ rezolucji poświęconych prawu procesowemu (22 - prawo egzekucyjne, 11 - przewód sądowy, 14 -inne), Między tronem ..., s. 221-222.

${ }^{44} \mathrm{Z}$ materiału źródłowego badanego przez A. Czaję wynika, że rozstrzygnięcia poświęcone postępowaniu egzekucyjnemu stanowiły 13\% wszystkich rezolucji, Między tronem..., s. 221.

${ }^{45}$ Rezolucja nr 41 z 18.02.1785 r., Zbiór rezolucji..., 1788, s. 26. 
I tak, tematyce wyroków poświęcono rezolucję wydaną na żądanie Stefana $\mathrm{Aksaka}^{46}$, żalącego się na urząd grodzki, który w sprawie jego sporu ze starostą, „w sądzie swoim dekret (...) przez powtórny swój wyrok zupełnie odmienił”. Jednocześnie wnioskodawca dopraszał się ,pierwszego dekretu i procesu prawnie nastąpionych egzekucji, albo tej sprawy do ziemstwa odesłania”. Ponieważ, jak wynika z rezolucji, Rada nie otrzymała w tej sprawie żadnych wyjaśnień ze strony urzędników grodu ani wspomnianego starosty, konsyliarze zgodnie z przewidzianymi prawem kompetencjami uznali, że „Rada Nieustająca nie mająca mocy sądowej, ani dekretów rozeznawać, ani spraw do sądu odsyłać nie może”. Równocześnie jednak stwierdzili, że ,jako prawa wszelkim urzędom i jurysdykcjom sądowym, swoje dekreta odmieniać i przesądzać zabraniają, tak tym bardziej sądy primae instantiae mocą tych praw są związane, których dekreta wyższych sądów rozeznaniu podlegają"47.

W grupie rezolucji poruszających kwestię apelacji znalazło się natomiast rozstrzygnięcie na memoriał wystosowany do Rady przez sędziego ziemskiego rawskiego Jana Rzeszotarskiego ${ }^{48}$. Wnioskodawca, przywołując konstytucję pt. Przyspieszenie sprawiedliwości z 1775 r., zapytał, „,czy to co jest ustanowionym dla województwa łęczyckiego w nakazie grodowi tegoż województwa, aby strony nie kontentujące się dekretem grodzkim, via appellationis do ziemstwa tegoż województwa odsyłał, służyć ma za prawidło wszystkim grodom w obydwóch prowincjach koronnych?” Zdaniem konsyliarzy, rozciągnięcie na całą Koronę przyjętej dla ziemi łęczyckiej zasady dopuszczającej składanie apelacji z sądu grodzkiego, nie do Trybunału, a, dla usprawnienia wymiaru sprawiedliwości, do sądu ziemskiego, nie było możliwe. Rada uznała, że „prawo wzwyż wspomnione (...) jednemu województwu łęczyckiemu służy, gród więc tegoż województwa nie może przeczyć do ziemstwa apelacji, bez wyraźnego złamania prawa, które ma w celu szczególnie rzeczone województwo łęczyckie, nie powinno być rozciągnione do innych grodów"49.

Dalsze 3\% orzeczeń Rady Nieustającej obejmujących kwestie prawa procesowego, dotyczyło warunków korzystania z dylacji. W grupie tej znalazły się też rozstrzygnięcia wyjaśniające wprowadzoną w 1768 r., budzącą wiele wątpliwości instytucję communicatio documentorum.

${ }^{46}$ Stefan Aksak h. własnego - wojski większy łucki (1765-1778), cześnik łucki (1778-1779), podstoli włodzimirski (1779-1789), stolnik włodzimirski (1789-1790), Urzędnicy wołyńscy XIV-XVIII wieku, red. A. Gąsiorowski, Kórnik 2007, s. 155.

${ }^{47}$ Rezolucja nr 4 z 2.01.1778 r., Zbiór rezolucji..., 1785, s. 18.

48 Jan Rzeszotarski h. Junosza - komornik rawski, wojski mniejszy sochaczewski, cześnik mszczonowski, podstoli rawski, od 1776 r. sędzia ziemski rawski, poseł na sejm $(1776,1782,1784)$, członek Komisji Skarbowej Koronnej, sędzia sejmowy. Jego działalność jako sędziego ziemskiego była wysoko oceniana przez współobywateli woj. rawskiego, Z. Anusik i A. Stroynowski, Rzeszotarski Jan, PSB, t. XXXIV/1, z. 140, 1992, s. 50-51.

${ }^{49}$ Rezolucja nr 62 z 25.02.1777 r., Zbiór rezolucji..., 1785, s. 5. 
W sprawie odnoszącej się do tej materii interweniował w Radzie sąd ziemski wizki, pytając, jak należy postępować w przypadku, gdy „osoby we dwóch jurysdykcjach, to jest ziemstwie jednej ziemi, a w grodzie drugiej ziemi, w jednymże czasie, sprawy osobistości wymagające, przypadłe mając, gdzie raczej, czy w ziemstwie, czyli też w grodzie stawić się powinny? I co w jurysdykcji owej, gdzie nie stawają wnosić mają?" Rada, odwołując się do powszechnie stosowanej w prawie zwyczajowym instytucji odkładów, orze$\mathrm{kła}$, że „w sprawach osobistości w jednym czasie u różnych sądów wymagających, brania dylacji pro maiori, prawa krajowe dozwalają"50.

Odnośnie do tzw. komunikacji dokumentów, lubelski urząd grodzki zażądał natomiast wytłumaczenia czy, ,jeżeli w porządku egzekucji prawa z $1768 \mathrm{r}$. [pt. Złączenie Trybunału Koronnego - M. G.] strona na zwłokę sprawiedliwości communicationem documentorum biorąca, a dekretowi tejże komunikacji zadość nie czyniąca, nie powinnaby być karana, jako przed tym prawem contraveniens dekretowi dilationis ad munimenta karana bywała?" Wnioskodawcy poruszyli więc problem rozciągnięcia stosowanych dotychczas $\mathrm{w}$ prawie zwyczajowym sankcji wobec osób, które pomimo przyznania im dylacji, nie dostarczyły niezbędnych w sprawie dokumentów, na stronę korzystającą z nowej instytucji tzw. communicatio documentorum. Rada uznała jednak, że ,wyżej wyrażone prawo zniosło instancję dilationis ad munimenta, tym samym i rygor supra contravenientes takowym dylacjom ściągniony, jest uchylony" 51 .

Obok wyżej wymienionych, w rezolucjach dotyczących prawa procesowego, poruszano też zagadnienia praw i obowiązków stron procesu, postępowania dowodowego (w tym przede wszystkim składania zeznań przez świadków). Wreszcie zajmowano się m.in. problematyką procesu granicznego, przepisów ekstradycyjnych w sprawie zbiegłych chłopów czy zasad sporządzania i kładzenia pozwów.

Wysoka liczba rezolucji traktujących o prawie procesowym to przede wszystkim skutek złożonego i skomplikowanego systemu norm, częściowo wykształconych w drodze zwyczaju, częściowo uregulowanych nie zawsze przejrzystymi przepisami sejmowych konstytucji. Szczególnie ułomna, o czym świadczą licznie nadsyłane do Rady zapytania, była wydłużona, wieloetapowa i sprzyjająca unikaniu realizacji wyroków procedura egzekucyjna. Nie zawsze jasne, niejednolite zresztą we wszystkich województwach, zasady składania apelacji, także budziły, jak wynika ze statystyk, wiele wątpliwości interpretacyjnych.

Prawie $20 \%$ ogółu rezolucji stanowiły postanowienia poświęcone interpretacji prawa prywatnego ${ }^{52}$. Na pierwszy plan wysuwają się tu sprawy dotyczące

\footnotetext{
${ }^{50}$ Rezolucja nr 321 z 23.04.1784 r., Zbiór rezolucji..., 1786, s. 10.

${ }^{51}$ Rezolucja nr 246 z 4.07.1777 r., Zbiór rezolucji..., 1785, s. 12.

${ }^{52}$ A. Czaja ustalił liczbę rezolucji dotyczących prawa prywatnego na 50 (30\%), Między tronem..., s. 221.
} 
opieki i kurateli (4\% rezolucji) - głównie zagadnienia wyboru opiekuna, zakresu jego obowiązków czy warunków przydzielania kuratora wdowom i rozwódkom. W dużym stopniu wnioski i udzielane na nie odpowiedzi związane były tu z najnowszą (1775 r.) ustawą poświęconą temu właśnie zagadnieniu.

Konstytucja, o której wyżej mowa, zatytułowana Ubezpieczenie sierot $i$ wdów, zdaniem autora jednego z memoriałów - występującego pod imieniem Jakub - niedostatecznie wyjaśniała, „czyli białogłowy nie owdowiałe, ale sposobem procesu od ślubów małżeńskich i obowiązków onychże uwolnione, bezdzietne, żadnej substancji mężowskiej nie posiadające, swoje tylko dziedziczne dobra dzierżące i onemiż rządzące, podpadają pod obowiązek prawa, względem dodawania kuratorów wdowom, ustanowionego?” Ustawa, co trzeba podkreślić, miała na celu szczególną ochronę interesu m.in. wdów, którym jak stwierdzono w ustawie „ziemstwa i grody (...) kuratorów posesjonatów dodawać powinny" 53 . Problem przedstawiony w memoriale dotyczył natomiast kobiet, których małżeństwo zostało unieważnione, a o których sama konstytucja nie wspominała. Trzymając się precyzyjnie słów ustawy, konsyliarze uznali, że osoby takie ,pod obowiązek wyżej rzeczonego, względem dodawania kuratorów wdowom (jeżeli tego same żądać nie będą) nie podpadają prawa"54. Wynikało z tego, że rozwiązanie przyjęte w ustawie nie zamykało tym kobietom prawa do starania się o przydzielenie kuratora, a jedynie zwalniało sądy z obowiązku działania w tej sprawie z urzędu.

$3 \%$ rezolucji poruszało temat ogółu praw i ograniczeń duchowieństwa w obrocie dobrami ziemskimi, zakładaniu nowych podmiotów kościelnych oraz zasad odprowadzania dziesięciny. Interwencje w tego rodzaju sprawach spowodowane były najczęściej sporami między podmiotami kościelnymi a stroną świecką.

Dowodem zainteresowania tą problematyką jest memoriał dotyczący interpretacji ustawy sejmowej pt. Ordynacja Rzeczypospolitej dóbr ziemskich dziedzicznych z 1635 r. Autor wniosku zapytał konsyliarzy: ,jeżeli jakowej zdrożności przeciwko prawu nie uczyni, gdy na fundamencie konstytucji (...) w słowach »Jeżeliby zaś kto ubogiemu kościołowi farnemu we wsi darował na podratowanie sztukę jaką gruntu, to nie ma być pro contraventione temu prawu poczytano« gruntów do kościoła farnego parafialnego należących, zamianę zrobi in aequivalenti praevio loci ordinarii tum parochii ac collatorum consensu?” I dodał jednocześnie: „gdyż to prawo nadawać grunta pozwala, nie zdaje się zabraniać czynienia zamiany”. Rada uznała taką wykładnię przepisu i stwierdziła, że ,gdy wyżej rzeczone prawo pozwala nadania sztukę jaką gruntu kościołowi ubogiemu farnemu, tym bardziej zamianę gruntu za grunt (...) żadnym prawem nie jest zabroniona" ${ }^{, 55}$.

\footnotetext{
$53 \quad V L$ VIII, f. 183.

${ }^{54}$ Rezolucja $n r 13$ z 2.01.1778 r., Zbiór rezolucji..., 1785, s. 116.

${ }^{55}$ Rezolucja nr 263 z 25.01.1782 r., Zbiór rezolucji..., 1785, s. 59.
} 
Ponadto, Rada Nieustająca zajmowała się problematyką prawa spadkowego (niecałe 2,5\% rezolucji) - przede wszystkim zagadnieniem dziedziczenia ustawowego, głównie rozstrzygając kwestię obowiązywania prawa kaduka. Zainteresowanie tą gałęzią prawa uzasadniał z pewnością brak precyzyjnych i jasnych zasad spadkobrania, czego wyrazem były zresztą od lat wysuwane postulaty ustawowego uregulowania tej kwestii.

Stan prawny w tej materii ilustruje dość trafnie problem przedstawiony Radzie Nieustającej przez Jana Komara. Nadesłany przez niego wniosek zawierał prośbę wytłumaczenia konstytucji $O$ Kadukach z roku 1588. Postanowiono w niej, ,iż się kaduk szlacheckich dóbr, tak ojczystych, jako macierzystych, rozumieć nie może, dokądby stawało powinnych krewnych, utriusque sexus et utraque linea: która nie może ani ma być przerwana quarto, quinto et perconsequens ulteriori gradu propinquitatis, ale dokąd się jedno może wywieść ius successionis legitimae usque ad octavum gradum inclusive" 56. W świetle tak skonstruowanej normy, autor memoriału zapytał, „czy w niedostatku sukcesorów ojczystych ad octavum usque gradum; sukcesorowie macierzyści; i wzajemnie w niedostatku sukcesorów macierzystych; sukcesorowie ojczyści krwie respective każdej linii w sobie niemający, sukcedować mogą? Czyli też po bezpotomnym jednej linii zejściu, kaduk bezpotomnej linii, oddzieliwszy fortunę drugiej linii, majątek posiadać ma?" Jak widać, według wnioskodawcy tłumaczenie przepisu mogło być dwojakie. Trudno się z nim nie zgodzić, bo cytowane prawo rzeczywiście nie było jasne. Autor pytania słusznie zauważył, że z ustawy nie wynika w sposób jednoznaczny, kiedy pozostawiony majątek lub jego część podlegały przepadkowi na rzecz monarchy; czy do przejęcia przez fiscus spadku wystarczał brak spadkobierców jednej tylko linii (co pozwalałoby przejąć przez króla połowę pozostawionego majątku), czy też warunkiem było wygaśnięcie obu linii, aż do ósmego stopnia pokrewieństwa. Prawdopodobnie Jan Komar, być może jako najbliższy żyjący krewny zmarłego, w obliczu wygaśnięcia drugiej linii, zainteresowany był przejęciem całości spadku i liczył na potwierdzenie przez Radę Nieusta-

${ }^{56}$ VL II, f. 1210. Ustalenie ósmego stopnia pokrewieństwa rzymskiego systemu liczenia, jako najdalszego, poza którym spadek stawał się kadukiem, wykształciło się dopiero w wieku XVI. Pierwotnie spadek stawał się puścizną już w braku potomstwa. Dziedziczenie krewnych bocznych pojawiło się do końca XIII w., początkowo dopuszczani byli do niego jedynie krewni do czwartego stopnia komputacji rzymskiej. Dopiero z biegiem czasu rozszerzono prawo do spadkobrania na coraz dalszych krewnych, aż do wspomnianej ustawy z roku 1588. Stopniowe rozszerzanie kręgu dziedziców miało na celu maksymalne ograniczenie królewskiego prawa kaduka w stosunku do dóbr szlacheckich. P. Dąbkowski, Prawo prywatne polskie, t. II, Lwów 1911, s. 60, Z. Kaczmarczyk, B. Leśnodorski, Historia państwa i prawa Polski, t. II, red. J. Bardach, Warszawa 1968, s. 294, S. Płaza, Historia prawa w Polsce na tle porównawczym, cz. I, Kraków 2002, s. 299. Na sejmie 1778 r. marszałek koronny S. Lubomirski domagał się rozszerzenia prawa do spadku, z wyłączeniem prawa kaduka, do dwunastego stopnia pokrewieństwa. W odpowiedzi król Stanisław Poniatowski stwierdził, że przyjęcie takiego rozwiązania jest ograniczeniem go w „ostatniej cząstce prerogatywy rozdawniczej”, W. Filipczak, Sejm 1778, s. 185. 
jącą pierwszego z sugerowanych przez siebie, możliwych rozwiązań. Pozwoliłoby mu to, niezależnie od pokrewieństwa z drugą linią, objąc spadek, bez ryzyka utraty jego części na rzecz króla. Rada Nieustająca, interpretując powyższy przepis konstytucji, uznała jednak, że „wyraźnie in retrusionuem iuris caduci, ius successionis legitimae usque ad octavum gradum inclusive wyprowadzać każe, którego gdyby sukcesorowie macierzyści krwi ojczystej, a ojczyści macierzystej nie mając, wywieść nie mogli, w takim więc przypadku rezolucja substantiarum nastąpić i fortuny linii, której non extant successores, tam masculi, quam femelli, według prawa sub ius caducum, inna zaś sukcesorom krwi dostać się powinna" 57 .

Pozostałe rezolucje z zakresu prawa prywatnego przede wszystkim poruszały zagadnienia ochrony własności, umów pożyczki (i wysokości prowizji), emfiteuzy, zastawu i ogólnych zasad zawierania transakcji ${ }^{58}$.

Znamienny jest fakt, że zaledwie nieco ponad 2,5\% wszystkich rezolucji poświęcono zagadnieniom prawa karnego ${ }^{59}$. Połowa spraw w tej grupie dotyczyła zresztą tematyki więziennictwa, zasad odbywania kary i środków finansowych przeznaczonych na utrzymywanie więźniów. Szczególnie ostatnia kwestia, wobec braku rozbudowanego i sprawnie działającego systemu więzień, stanowiła istotny problem, z którym należało się jak najszybciej uporać.

Sytuacja była trudna, o czym świadczy jeden z nadesłanych memoriałów, autorstwa sędziego ziemskiego gnieźnieńskiego - Józefa Radzimińskiego ${ }^{60}$, szukającego prawnych możliwości rozwiązania, przynajmniej doraźnie, pilnej kwestii przetrzymywania aresztantów. Zapytał on Radę, ,czy w sprawie kryminalnej o zabój, kryminalistów oskarżonych, przyaresztowanych pignus responsionis nie mających, osobiście się przed sądem stawiących i komparycję piszących, sąd minoris subsellii mógłby wzorem Trybunału sub custodiam wojska tantisper dysponować? I czyliby wojsko, tych oskarżonych kryminalistów (kosztem strony utrzymywać mianych) przyjąć i póty, póki finalny dekret in minori subsellio, lub ex appellatione $\mathrm{w}$ Trybunale nie wypadnie, trzymać powinien?" Rada, świadoma zapewne braku wystarczającej infrastruktury penitencjarnej, przychyliła się do wniosku, oświadczając, że „kryminaliści (...) przez rezolucję sądową do aresztu wskazani, pod strażą wojska kosztem stro-

${ }^{57}$ Rezolucja nr 386 z 24.10.1777 r., Zbiór rezolucji..., 1785, s. 64.

${ }^{58} \mathrm{~W}$ zestawieniu autorstwa A. Czai rezolucje obejmujące problematykę prawa zobowiązaniowego (22 przypadki) stanowiły $13 \%$ ogółu orzeczeń, Między tronem ..., s. 236 . W poniższym zestawieniu odsetek ten wyniósł - dla porównania - 8\%.

${ }^{59} \mathrm{~W}$ tym przypadku poniższe ustalenia wyraźnie odbiegają od wyników badań A. Czai, w świetle których odsetek ten kształtuje się na poziomie prawie 11\%, Między tronem..., s. 221.

${ }^{60}$ Józef Radzimiński h. Lubicz - sędzia ziemski gnieźnieński (od 1768 r.), poseł na sejm (1773, 1782, 1786, 1788), sędzia sejmowy, wojewoda gnieźnieński (1790), senator (1790), sędzia pokoju (1807), senator - wojewoda (1810), Urzędnicy wielkopolscy XVI-XVIII w., red. A. Gąsiorowski, Kórnik 1987, s. 44, J. Kowecki, Radzimiński Józef, PSB, t. XXX/1, z. 124, s. 98-99. 
ny, aż do ostatecznej rozprawy trzymani być mają, a to według praw sądom najwyższych jurysdykcjów służących, i przez też egzekwowanych" ${ }^{\prime}$.

Zaledwie kilka rezolucji poruszało natomiast sprawy ściśle związane z prawem karnym materialnym i procedurą karną (były to orzeczenia potwierdzające wprowadzenia bezwzględnego zakazu uzyskiwania zeznań poprzez tortury). Niewykluczone, że przyczyn znikomego zainteresowania tą gałęzią prawa można szukać w braku reform. Jak wyjaśnia J. Michalski, większość przestępców ściganych przez prawo rekrutowała się spośród plebejuszy, podlegających sądownictwu miejskiemu. Ustawodawstwo państwowe w zasadzie nie zajmowało się tymi sądami i obowiązującym w nich prawem - problem reform przeprowadzonych drogą konstytucji sejmowych poświęconych tej problematyce $\mathrm{w}$ zasadzie nie istniał ${ }^{62}$.

Pozostałe blisko 7\% rezolucji poruszało problematykę podatków, spraw miast i mieszczan, organizacji sejmików ziemskich, wyjaśniało wątpliwości wokół ustawy o Radzie Nieustającej, nobilitacji oraz innych pojedynczych zagadnień.

Przykładem jednej z takich rezolucji jest orzeczenie w sprawie tzw. podatku foraliorum, który był przedmiotem zainteresowania Komisji Skarbowej Koronnej. Jej członkowie mając na względzie konstytucję z 1764 r. pt. Zniesienie foraliorum, zapytali, czy ustawa ta ,ściąga się do miast dziedzicznych, albo nie?" Rada Nieustająca zaznaczyła, że już pierwsze słowa wspomnianej konstytucji: „...dozwalany prawami sposób podatku, nazywany foralia, czyli targowe, kupczącym krzywdę, a mieszkającym w miastach królewskich..."63, wyjaśniały wszelkie wątpliwości, i jak oświadczyła w dalszej części: ,zakaz foraliorum niżej w tym prawie wyrażony, do miast tylko naszych królewskich ściągać chciała, przeto stosować onego do dóbr ziemskich nie można"64.

Oprócz określenia materii będących przedmiotem rozstrzygnięć Rady Nieustającej, analiza rezolucji pozwala także ustalić przyczyny, z tytułu których występowano do niej z zawartymi w memoriałach pytaniami. Podobnie jak w przypadku, poruszanej w pismach, zróżnicowanej problematyki, również powód i okoliczności powstałych wątpliwości prawnych były niejednolite. Jednocześnie interesująca jest reakcja samej Rady na problemy, które zdecydowały o złożeniu wniosku i sposób rozstrzygania przez konsyliarzy określonego rodzaju spraw.

Jedną z najczęstszych przyczyn sygnalizowanych w memoriałach wątpliwości były trudności związane z interpretacją aktów prawnych zawierających zbyt ogólne, nieprecyzyjne lub niejasne sformułowania. W niektórych przypadkach przepisy sejmowych konstytucji były, zdaniem pytających, w tak

\footnotetext{
${ }^{61}$ Rezolucja nr 370 z 28.07.1786 r., Zbiór rezolucji..., 1788, s. 122.

${ }^{62}$ J. Michalski, Studia nad reforma..., s. 249.

${ }^{63}$ VL VII, f. 333.

${ }^{64}$ Rezolucja nr 348 z 3.10.1777 r., Zbiór rezolucji..., 1785, s. 47.
} 
dużym stopniu niedokładne, że tłumaczyć je można było w różny sposób. W tego typu sytuacjach odczytanie rzeczywistej intencji prawodawcy było istotnie utrudnione, a użycie w tekście ustawy niezrozumiałej frazy, zwrotu bądź terminu wieloznacznego uzasadniało, w przekonaniu wnioskodawców, złożenie prośby o wykładnię przepisu.

Przykładem budzącego takie zastrzeżenia aktu była konstytucja pt. Ustanowienie prowizji ubezpieczenie kredytorów z 1775 r., regulująca kwestię wysokości oprocentowania pożyczek. Swoje obiekcje w tej sprawie przedstawił konsyliarzom wschowski podsędek - Ludwik Herstopski ${ }^{65}$. Zgodnie z ustawą, „gdyby zaś debitor na terminie tym, którym się swojemu kredytorowi oddać prowizją obowiązał, prowizji podług dokumentu nie zapłacił, tedy pro poena od uchybionego terminu, prowizją już nie pięć, ale po siedm od sta swojemu kredytorowi, aż do zapłacenia sumy, płacić obligowany będzie"66. Wątpliwości autora memoriału dotyczyły terminu, od którego należało naliczać wyższą, siedmioprocentową prowizję. Choć wydaje się, że zwrot „od uchybionego terminu" jest wystarczająco precyzyjny, w opinii Herstopskiego prawo to thumaczyć można było na dwa sposoby. Zapytał więc: „Jeżeli podług tych słów prawa, debitor nie zapłaciwszy na oznaczonym terminie po pięć od sta swojemu kredytorowi, ma i tę roczną niezapłaconą, po siedm zapłacić, czyli też dopiero ab actu contraventionis ta prowizja po siedm od sta prawem oznaczona, płacona być ma?" Wnioskodawca brał więc pod uwagę również taką ewentualność, wedle której naliczanie wyższej prowizji obejmowało okres sprzed terminu wymaganej spłaty, co miało stanowić dodatkową sankcję dla nierzetelnego pożyczkobiorcy. Takiej interpretacji nie potwierdziła jednak Rada Nieustająca, stwierdzając jednoznacznie, ,iż wyżej wyrażone prawo jasnemi wyrazami determinuje, że dopiero ab actu contraventionis, prowizja po siedm od sta rachowana i przysądzona być ma"67.

Problem z prawidłową wykładnią mógł być także rezultatem użycia w aktach prawnych pojedynczych słów o zróżnicowanym - wąskim albo szerokim znaczeniu. Niedoprecyzowanie terminów wprowadzonych przez prawodawcę mogło pociągnąć za sobą negatywne konsekwencje w postaci przyjmowania różnych interpretacji, a w rezultacie pojawiających się na tym tle sporów. Stąd też, na przykład, w odniesieniu do ustawy pt. Złaczenie Trybunału Koronnego swoje zastrzeżenia zgłosił Radzie Nieustającej warszawski komornik ziemski - Stanisław Kochanowski. Postulował on uściślenia przez konsyliarzy przepisu poświęconego wzruszalności umów zawartych z użyciem podstępu. Otóż zgodnie z brzmieniem ustawy: „wszystkie ogólnie transakcje między

${ }^{65}$ Ludwik Herstopski h. Drogosław - pisarz wschowski (1763-1765), podsędek wschowski (1765-1785), sędzia wschowski (1785-1788), Urzędnicy wielkopolscy XVI-XVIII w. Spisy, red. A. Gąsiorowski, Kórnik 1987, s. 205.

${ }^{66}$ VL VIII, f. 181.

${ }^{67}$ Rezolucja nr 147 z 6.05.1777 r., Zbiór rezolucji..., 1785, s. 133. 
(...) starszemi i młodszemi bracią, w ufności, rzetelności i sprawiedliwości zawarte, a w których się podejście, lub laesio iuris naturea jawnie i dowodnie pokaże (...) kasowane, et nullius valoris być powinny" ${ }^{\prime 8}$. Prawdopodobnie w związku z wnioskiem, jaki trafił do warszawskiego sądu, Kochanowski zwrócił uwagę, że użyty w konstytucji termin „brać” był bardzo szeroki, mógł bowiem oznaczać zarówno rodzeństwo, jak i krewnych dalszego stopnia. Zapytał więc konsyliarzy: „Czyli ten wyraz prawa «między bracią starszemi i młodszemi» może być aplikowanym do dalszych braci, choćby nierodzonych?" Rada wytłumaczyła zainteresowanemu, że wspomniane prawo „,nie tylko młodszym braciom, ale nawet nikomu z krewnych, przez takowe transakcje in iure natura pokrzywdzonemu nie zabroniło (gdy u sądu jawnie i dowodnie pokrzywdzenie swoje okaże), aby o skasowanie rzeczonych transakcji, nie mógł czynić podług prawa, ubi de iure"69.

Jedną z cech charakteryzujących systemy prawa stanowionego jest możliwość wystąpienia zjawiska wewnętrznej sprzeczności, czyli tzw. kolizji norm. Prawo obowiązujące na ziemiach polskich $\mathrm{w}$ omawianym okresie nie było w tej kwestii wyjątkiem. Wzrost liczby konstytucji uchwalonych, w szczególności w latach 60. i 70. osiemnastego stulecia, spowodował, że jednocześnie rosła także liczba przepisów wzajemnie sprzecznych. Ustawodawca nie zawsze był w stanie temu zapobiec, dopuszczając do poszerzania się skali problemu. Istnienie sprzecznych norm prawnych obnażała praktyka i dopiero na etapie stosowania poszczególnych przepisów dochodziło do sytuacji, w których zarówno urzędy, jak i osoby prywatne stawały przed problemem podporządkowania się jednej z norm, przy równoczesnej konieczności złamania innej. Wśród zapytań nadesłanych do Rady Nieustającej znalazły się również memoriały poruszające zagadnienie sprzeczności praw.

Sprzeczność taka mogła polegać na tym, że zachowanie dozwolone przez jedną normę prawną, zakazane były przez inną. Świadczy o tym nota autorstwa podkanclerzego koronnego Jacka Małachowskiego ${ }^{70}$. Przypomniał on, że zgodnie z konstytucją pt. Złączenie Trybunatu Koronnego, „sprawy wszystkie, ile być mogą, na kadencji sędziowie odsądzać mają choćby i z przewleczeniem czasu"71. Ustawodawca wyraźnie więc zezwalał sądom na przedłużanie czasu ich kadencji, tak aby mogły one rozpatrzyć wszystkie wpisane do regestrów sądowych pozwy. To słuszne skądinąd rozwiązanie, intencją którego było skrócenie przeciągającego się nierzadko okresu oczekiwania na sądowy

${ }^{68} V L$ VII, f. 708.

${ }^{69}$ Rezolucja nr 314 z 25.04 .1786 r., Zbiór rezolucji..., 1788, s. 1.

${ }^{70}$ Jacek Małachowski h. Nałęcz - starosta ostrołęcki, piotrkowski, grodecki, radoszycki, wielokrotny poseł, sędzia Asesorii, deputat trybunalski, funkcję referendarza świeckiego pełnił w latach 1764-1780, konsyliarz Rady Nieustającej w 1776 r., kolejno podkanclerz (1780-1786) i kanclerz wielki koronny (1786-1793), Urzędnicy centralni i nadworni Polski XIV-XVIII wieku. Spisy, red. A. Gąsiorowski, Kórnik 1992, s. 184; A. Zahorski, Małachowski Jacek, PSB, t. XIX, 1974, s. 393-396.

${ }^{71} V L$ VII, f. 704. 
wyrok, nie do końca, jak zauważył Małachowski, można było pogodzić z szeregiem konstytucji, które dla odmiany - w celu zachowania czasowej dyscypliny sądzenia, nakazywały ścisłe przestrzeganie terminów przewidzianych dla poszczególnych roków sądowych ${ }^{72}$. Dlatego we wspomnianej nocie znalazło się pytanie: „Jeżeli konstytucja 1768 roku (...), wiąże lub nie? do zachowania go [kanclerza - M. G.] i te Jurysdykcje, dla których szczególne konstytucje czas sądów przepisujące, jedne pierwej w roku 1764 i 1766, drugie zaś pośledniejsze w roku 1775 i 1776 zaszły?" Warto podkreślić, że we wniosku mowa jest zarówno o ustawach uchwalonych przed, jak i po roku 1768, z którego pochodziła analizowana konstytucja pt. Złaczenie Trybunału Koronnego. Choć sam autor noty nie zwrócił na to szczególnej uwagi, fakt ten mógł mieć istotne znaczenie przy ustalaniu pierwszeństwa $\mathrm{w}$ stosowaniu jednej z dwóch sprzecznych norm prawnych. W odniesieniu bowiem do aktów z roku 1764 i 1766, ewentualne zastosowanie reguły kolizyjnej lex posterior derogat legi priori, oznaczałoby pierwszeństwo konstytucji z roku 1768. Skorzystanie z tej samej zasady w przypadku praw z lat 1775-1776, spowodowałoby zaś uchylenie przepisów ustawy pt. Złączenie Trybunatu Koronnego. Rada wyjaśniła, w pierwszej kolejności, ,iż konstytucja 1768 roku (...) jest późniejsza od konstytucji 1764 i 1766 roku, przeto rygorem swoim do odsądzania wszystkich wpisów na kadencjach sądowych, wiąże i te Jurysdykcje, które przed tymże prawem, czas do sądzenia, dwuniedzielny dłuższy lub krótszy, determinowany miały". $Z$ opinii tej wynikało więc, iż niezależnie od faktu, że starsze rozwiązania były, jak wspomniano, prawem szczególnym, w razie wystąpienia sprzeczności z lex generalis roku 1768, należało je uchylić. W dalszej części rezolucja brzmiała: „Nie zajmuje zaś ta konstytucja 1768 roku generalnością swoją tych Juryzdykcji, które później po niej, to jest prawem roku 1775 i 1776 uchwalonym, normale tempus do sądzenia mają wyznaczone"73. W tym przypadku nie było żadnych wątpliwości, że w zbiegu tych przepisów, pierwszeństwo mają normy uchwalone później, które dodatkowo miały charakter lex specialis w stosunku do generalnego prawa $\mathrm{z}$ roku 1768.

Kolejny przykład dotyczy sprawy kryminalnej zgłoszonej pod rozstrzygnięcie Rady przez gród wileński. Do niego bowiem rodzeństwo zamordowanego duchownego pozwało podejrzanych o ten czyn braci zakonnych. Jako podstawę swojego działania krewni zmarłego podali art. XXX, rozdz. IV Statutu Litewskiego, który między innymi, sprawy o zabójstwo przekazywał sądom grodzkim ${ }^{74}$,

72 Przykładowo, w myśl konstytucji z roku 1766 kadencja sądu ziemskiego województwa krakowskiego miała trwać każdorazowo 3 tygodnie, J. Rafacz, Dawny proces polski, Warszawa 1925, s. 29.

${ }^{73}$ Rezolucja nr 44 z 1.03.1785 r., Zbiór rezolucji..., 1788, s. 59.

${ }^{74}$ Ustawujem (...) aby Wojewodowie i Starostowie Nasi Sadowi sądzili (...) o te artykuty, mianowicie tu opisane to jest (...) 12. O glowę szlachecka, także i poręczników takich, któryby o pochwatkę na gardlo, abo ogniem kogo ręczyli. 
a także konstytucję z roku 1726 - Trybunat W.X. L. Compositii Iudicij, stwierdzającą, że ,similiter causae facti między świeckiemi a duchownemi agitujące się, sprawy także kryminalne (...) nie gdzieindziej, ani w Konsystorzu, tylko w Trybunale W. X. Litewskiego mixti fori ante et post appellationem od Urzędów Ziemskich, Grodzkich, i innych minoris subsellij Sądów, non obstante etiam litispendentia, w kole świeckim sądzić się mają" 75 . Obydwa prawa poddawały więc duchownych pod sąd jurysdykcji świeckich, w pierwszej instancji - grodu, drugiej - Trybunału. Oskarżeni zakonnicy, jak wynika z treści memoriału, ,nie chcąc być sądzonymi w Grodzie, wzywają prawa statutowego art. XXXII z rozdz. III, we wszystkich do duchownych pretensjach, świeckim osobom w Sądzie Biskupim; a po apelacji, w Sądzie Duchownego Trybunału rozprawiać się nakazującego" "76. Ponadto, w odpowiedzi na pozew rodzeństwa zabitego zakonnika, konsystorz W. przywołał szereg kolejnych aktów prawnych: wydany dla duchowieństwa przywilej Zygmunta I z roku 1542, traktat polsko-litewski (1569), czy konstytucję z 1635 r. - wszystkie nakazujące w sprawach przeciwko duchownym kierować pozwy do sądu duchownego. Odrzucił zarazem możliwość powoływania się w tej sprawie na wspomniany przez rodzinę ofiary artykuł statutu, argumentując, że „w ten czas tylko kiedy duchowni ponoszą krzywdy od świeckich osób, mają też świeckie osoby pozywać do Ziemstw lub Grodów”. Podkreślił także, iż obowiązującą w tym przypadku zasadą winna być reguła actor sequitur forum rei, co oznaczało, że przytaczana przez krewnych zamordowanego, konstytucja o Trybunale, która jak stwierdził, nie objaśniała, „która strona jest skarżąca, a która oskarżoną”, nie mogła stanowić w tej sprawie podstawy prawnej. Rozstrzygając spór, Rada Nieustająca orzekła, że „gdy konstytucja 1726 (...) jest późniejszą od praw, w odpowiedzi konsystorza W. przywiedzionych; przeto w wydarzonym przypadku popełnionego kryminału, w którym duchowne i świeckie osoby wspólnictwo i uczestnictwo mieć mają, jest forum Sądu Trybunalskiego Judicii Compositii ex apellatione; a in prima instantia (...) w Grodzie lub Ziemstwie". Dodano równocześnie, że „w tej zaś sprawie, jako in re objecti criminis obsessionis viae publicae et inde emanati homicidii, w Grodzie, a nie gdzie indziej forum być powinno" "77. Rada podzieliła więc stanowisko oskarżycieli, a wątpliwości rozstrzygnięto zgodnie z zasadą lex posterior derogat legi priori. Tym samym przepisy starsze, których zastosowanie w tym przypadku sugerowała strona duchowna, w konfrontacji z prawem uchwalonym później, nie mogły być podstawą w rozwiązaniu opisanej sprzeczności.

Kwestia relacji: prawo zwyczajowe - ustawa wyraźnie zarysowana została w memoriale kijowskiego urzędu grodzkiego. Sygnalizowane kontrower-

${ }^{75}$ VL VI, f. 486.

${ }^{76}$ A jeśliby od samych osób duchownych $w$ czymkolwiek $w$ tych rzeczach wzwyż pomienionych, krzywda się komu działa, tedy o to także do Xiędza Biskupa abo Urzędu jego na rok pozwani być mają.

${ }^{77}$ Rezolucja nr 350 z 21.05.1784 r., Zbiór rezolucji..., 1786, s. 84. 
sje odnosiły się tu do zagadnień procesowych i dotyczyły fragmentu ustawy pt. Złaczenie Trybunału Koronnego z 1768 r., poświęconego nowym zasadom communicatio documentorum. Wyjaśnić trzeba, że w celu przyspieszenia i usprawnienia procesu, w miejsce fakultatywnie branej dylacji ad munimen$t a^{78}$, konstytucja wprowadzała obowiązek wzajemnego komunikowanie sobie dokumentów przez spierające się w sądzie strony, „w sprawach zadawnionych od lat dziesiąciu i wyżej”. Nie do końca jasny zdaniem urzędników miał być natomiast przepis regulujący, w którym terminie dokumenty te winny być dostarczone. Konstytucja stanowiła, ,aby in primo termino (...) nakazywana była komunikacja documentorum, per partes utrasque, mediante comprobatione juratoria przez strony osobiście stawające, pro sequenti cadentia Iudiciorum (...) Disjudicatio zaś causae, ex iisdem documentis communicatis, dopiero na przyszłej kadencji subsequi $\mathrm{ma}^{79}$ ". Tłumaczono to na dwa sposoby. Wedle pierwszej, możliwej zdaniem urzędników interpretacji, strony zobowiązane do osobistego stawiennictwa, w pierwszym terminie rozprawy miały dostarczyć dokumenty i złożyć wymaganą prawem przysięgę ${ }^{80}$. Wówczas, jak zakładano, rozstrzygnięcie sporu powinno nastąpić ,nie na trzeciej, lecz na drugiej następującej post primum terminum kadencji”. Jednak, co podkreślili autorzy pytania, praktykowany powszechnie zwyczaj, że ,in primo termino strony osobiście nie stają" skłaniał do odmiennego rozumienia ustawy. Zgodnie z nim całe postępowanie przesuwało się wtedy w czasie o jedną kadencję. Na pierwszym terminie stwierdzano jedynie ,za wniesieniem strony, że jest inveterata causa"81. Wtedy to również ,wypada dekret dilationis communicationis Documentorum ad proximos, dopiero in proximis strony osobiście z dokumentami stawają, summariusze piszą, i zaprzysięgają; a sądzenie sprawy znowu zawiesza się do przyszłej, to jest trzeciej kadencji”. Urzędnicy grodzcy stanęli więc przed dylematem, pytając Radę: „Czyli więc takowe w zwyczaj wzięte sądzenie, zgadza się z myślą konstytucji: czyli też ma być skrócone podług wyżej wyrażonego tej konstytucji rozumienia?” Przywołany przykład jest dowodem na silne przywiązanie do zwyczaju i jego wpływ na interpretację prawa stanowionego. Obowiązująca dotąd powszechna praktyka procesowa determinowała określony sposób myślenia i tłumaczenia przepi-

${ }^{78}$ Dilatio ad munimenta, o której wspomina konstytucja, polegała na odroczeniu terminu procesu sądowego albo dla dostarczenia przez stronę bliżej nie wymienionych dokumentów (dilatio simplex ad munimenta), albo dokumentów wyraźnie przez nią określonych ze wskazaniem na fakt, który tymi dokumentami strona zamierzała udowodnić (dilatio ad munimenta nominata seu specificata); O. Balzer, Przewód sądowy polski w zarysie, Lwów 1935, s. 102; S. Kutrzeba, Dawne polskie prawo sądowe w zarysie, Lwów 1927, s. 90.

${ }^{79} V L$ VII, f. 702.

${ }^{80}$ Konstytucja mieć chce stron osobistość, na tej in primo termino kadencji; oraz komunikacja documentorum, i onej zaprzysiężenie.

${ }^{81}$ Chodziło o stwierdzenie, że sprawa jest zadawniona, trwa, jak warunkowała konstytucja, co najmniej od 10 lat. 
sów ustawowych. W tym przypadku zresztą słusznie, jak podkreśliła bowiem, przychylając się do sugestii kijowian, sama Rada, ,konstytucja z 1768 r. (...) wyraźnie nie na pierwszej ex citatione kadencji, ale na drugiej czynić komunikację każe, a późniejszym swoim wyrazie (...) wyraźnie uczy, iż rozsądzenie sprawy nie na tej kadencji, na której czyni się komunikacja, ale na przyszłej dopiero subsequi ma i na mocy tego prawa jak doniesienie urzędu [kijowskiego - M. G.] uczy, zwyczaj z tym prawem zgodny ustanowiony został; przeto bez naruszenia prawa odmieniony być nie może"

Warto wspomnieć, że przyczyną składanych zapytań mógł być także brak wśród obowiązujących w danej prowincji przepisów prawa rozwiązań pozwalających rozstrzygnąc zaistniały problem. Nie zawsze oznaczało to pozostawienie wniosku bez merytorycznej odpowiedzi. Z pomocą przychodziło w takim przypadku prawo litewskie. Dowodzi tego przykład rezolucji, która wyszła w odpowiedzi na memoriał sędziego ziemi nurskiej - Franciszka Śląskiego. Opisany przez niego przypadek dotyczył sporu rodzinnego o podział dóbr dziedzicznych leżących na obszarze dwóch województw: podlaskiego i mazowieckiego. Starszy z braci złożył w tej sprawie pozew do sądu ziemskiego powiatu nurskiego (wschodnia część Mazowsza). Ten zaś „wyznaczył kondescensję, do podziału substancji, na której młodsza głowa dała się skondemnować". Jak można jednak przeczytać dalej, ów młodszy z braci tłumaczył swoją nieobecność na roczku sądowym, terminem w ziemstwie bielskim (województwo podlaskie), w którego okręgu jurysdykcyjnym leżały pozostałe, będące przedmiotem sporu dobra. Z relacji Śląskiego wynika, że „gdy powtórnie sprawa w Sądzie Ziemskim Nurskim przypadła, młodsza głowa pokładała termin do Trybunału Koronnego". Ponieważ w myśl obowiązującego prawa, sprawy niewniesione do sądu niższego nie mogły być kierowane do instancji wyższej, sąd zapytał: „,czyli całą sprawę o podział substancji rozsądzić powinien; ile że i prawo sprawom w Grodzie lub Ziemstwie nierozsądzonym do Trybunału ex cruda citatione, wychodzić zabrania?” Nie znalazłszy wśród konstytucji uchwalonych dla Korony odpowiedzi na zadane pytanie, Rada podjęła decyzję zastosowania we wspomnianym przypadku, prawa obcego. Odrzucając, przyjmowaną w innych przypadkach, możliwość zawieszenia sprawy do czasu podjęcia stosownych kroków prawodawczych przez sejm, konsyliarze orzekli, że „takowy przypadek (gdzie różność Jurysdykcji, nie tylko względem województwa, ale i prowincji ${ }^{83}$, sądzenie sprawy o dobra po różnych miejscach rozlegle tamuje) żadne koronne nie znajduje się prawo, któreby forum naznaczało". Co istotne, stwierdzili równocześnie: „przeto w niedostatku praw krajowych, Jurysdykcje wszelkie obcych używać

${ }^{82}$ Rezolucja nr 368 z 17.10.1777 r., Zbiór rezolucji..., 1785, s. 13.

${ }^{83}$ Ziemia nurska wchodząca w obręb województwa mazowieckiego należała do prowincji wielkopolskiej, ziemia bielska (woj. podlaskie) - prowincji małopolskiej, P. Burzyński, Prawo polskie prywatne, t. I, Kraków 1867, s. 320 i 324. 
mogą; tym przyzwoiciej Sąd Ziemski Nurski mieć może za prawidło konstytucją W. X. Litewskiego 1764 roku, Sejmu Koronacji Naszej „Trybunał X. Litewskiego jakie ma sądzić sprawy", która mieć chce: ażeby sprawy o dobra w różnych województwach i powiatach będące pro determinatione fori do Trybunału intentowane były" ${ }^{4}$. Rada nie podała, na jakiej podstawie dopuściła możliwość sięgnięcia po prawo obce. Faktem jest natomiast, iż wspomniana ustawa rzeczywiście mówiła, że „w sprawach sukcesyjnych (...) o dobra w różnych województwach i powiatach situm mające, jeżeliby strony litigia z sobą wiodące nie mogły się zgodzić, w którym Ziemstwie tę sprawę zacząć i konkludować mają, in tali casu powinny się zapozwać do Trybunału"85. Niestety Rada nie podała (bo i podać nie mogła), na której kadencji Trybunału: wielkopolskiej czy małopolskiej sprawę tę można było wnieść, a w tym konkretnym przypadku mogło to mieć istotne znaczenie. Ważny natomiast jest fakt, że orzeczenie to stanowi przykład recepcji prawa litewskiego na potrzeby mieszkańców polskich prowincji. Jak widać, Rada Nieustająca nie bała się wobec braku odpowiednich rozwiązań prawnych, zapożyczyć posiłkowo takowe z sąsiedniej Litwy ${ }^{86}$.

$\mathrm{Na}$ koniec podkreślić należy, że nie we wszystkich przypadkach Rada Nieustająca podejmowała się samodzielnego merytorycznego rozstrzygnięcia przedstawionego jej problemu. 25 wniosków z badanego okresu 1776-1786 spotykało się z odmową odpowiedzi na zadane pytanie lub realizacją zawartego w niej postulatu. Przyczyną był brak ustawowych kompetencji Rady, zwłaszcza odnośnie do wydawania rezolucji, które miałyby charakter prawotwórczy i oznaczały wkraczanie na obszar zastrzeżony dla ustawodawcy. Równie mocno zresztą zaakcentowano w prawie zakaz przejmowania przez nią uprawnień władzy sądowniczej. Na tych dwóch kwestiach skoncentrowana była pilna uwaga sceptyków i krytyków nowej instytucji. Dlatego postępowanie Rady, przede wszystkim w przypadkach, gdzie istniało ryzyko przed-

${ }^{84}$ Rezolucja nr 280 z 1.09.1778 r., Zbiór rezolucji..., 1785, s. 53.

${ }^{85}$ VL VII, f. 393.

${ }^{86}$ Warto w tym miejscu przypomnieć, że podczas prac nad Zbiorem praw sadowych Andrzeja Zamoyskiego w roku 1776 sporządzono tzw. Reguty fundamentalne do stanowienia prawa. Zalecały one, aby w przypadku, gdy prawo polskie znajdujące się $w$ statucie dawnym i konstytucjach sejmowych, było niewystarczające, pożyczać je ze Statutu Litewskiego, z eksceptów mazowieckich, z prawa chetmińskiego albo mazowieckiego, względnie, aby można było sięgać do praw zagranicznych, E. Borkowska-Bagieńska, ,Zbiór praw sądowych” Andrzeja Zamoyskiego, Poznań 1986, s. 68. Jednym ze zwolenników stosowania prawa litewskiego w Koronie był T. Ostrowski, który pisał: prawo litewskie (...) w niedostatku koronnego, zawsze $w$ sadach naszych miewa swoja powage, cyt. za A. Zakrzewski, Paradoksy unifikacji prawa i ustroju Wielkiego Księstwa Litewskiego i Korony XVI-XVIII w.,CPH, t. LI, z. 1-2, 1999, s. 231. W świetle dotychczasowych badań trwa dyskusja odnośnie stosowania Statutu Litewskiego w Koronie. Zdaniem części badaczy Statut był stosowany w Polsce jedynie jako prawo posiłkowe, według innych stanowił równorzędny z koronnym, obowiązujący system prawa. Więcej na ten temat J. Bardach, Statuty litewskie w Koronie Królestwa Polskiego [w:] Studia z dziejów państwa i prawa polskiego, t. IV, Łódź 1999, s. 19-28. 
stawienia jej zarzutów złamania przepisów, wymagało ostrożności i rozwagi. W szczególności zakaz kreowania prawa rodził niebezpieczeństwo takich oskarżeń. Przed urzędnikami Rady stało więc niełatwe zadanie. Granica między wykładnią a tworzeniem prawa często była bowiem trudna do zdefiniowania, a zarzuty o jej przekroczenie nierzadko opierały się na subiektywnej ocenie przedstawicieli politycznej opozycji.

Przykładowa rezolucja, w której Rada odmówiła realizacji zawartej w memoriale prośby, dotyczyła sprawy zasygnalizowanej przez sąd ziemski włodzimierski. W związku z długimi okresem oczekiwania na „sprawiedliwość w expediowanych kondescensjach", autorzy wniosku zaproponowali, aby „sędzia i podsędek, miał moc pozwoloną po dwóch instrumentować komorników, którzyby rotą sędziego wykonawszy przysięgę, expediować mogli kondescensje". Złożony przez sąd postulat musiał spotkać się z reakcją odmowną Rady, która oświadczyła, ,że żądanie (...) w memoriale (...) podanym wyrażone, względem wydania deklaracji pozwalającej sędziemu i podsędkowi przybrania komorników, należy do władzy prawo stanowiącej, a Rada Nieustająca w legislacją wdawać się nie ma danej sobie mocy: przeto że uskutecznione być nie może, My Król za zdaniem Rady deklarujemy"87. Dodać należy, że brak odpowiedniej kadry sądowej niższego szczebla spowalniał egzekucje wyroków i oddalał terminy przeprowadzenia w terenie czynności sądowych na tzw. kondescesach. Rozwiązaniem tego niekorzystnego stanu rzeczy było zwiększenie liczby komorników i vicesgerentów. Ta była jednak ustalona przez prawo, a pozwolenie na mianowanie kolejnych sądowych subalternów wyposażonych w kompetencje do wykonywania wspomnianych czynności wymagało zmian na poziomie ustawowym. Sędziowie, podkomorzowie czy starostowie podejmowali jednak próby obejścia takiej procedury, zwracając się o odpowiednią decyzję do Rady Nieustającej. Ta jednak konsekwentnie odmawiała im zgody na powoływanie dodatkowych urzędników, podkreślając wagę obowiązującego prawa i swój brak kompetencji dla wprowadzania w nim zmian.

Niewątpliwie, zadanie thumaczenia prawa, postawione przed Radą Nieustającą, nie należało do łatwych. Wymagało doskonałej orientacji w problematyce prawa stanowionego i zwyczajowego - co w braku spójnej, wspólnej dla wszystkich ziem kodyfikacji czyniło je jeszcze trudniejszym. Konsyliarze winni byli także dokonywać właściwej oceny stanu faktycznego - było to szczególnie ważne przy rozpatrywaniu wniosków osób prywatnych, starających się z pomocą różnych argumentów skłonić Radę do wydania rezolucji

${ }^{87}$ Rezolucja nr 216 z 20.11.1781 r., Zbiór rezolucji..., 1785, s. 92. 
korzystnych dla nich, choć nie zawsze zgodnych z przepisami prawa. Wreszcie, Rada musiała wykazać się zdolnością do działania w obliczu regularnych ataków opozycji i ciągłych zarzutów o wkraczanie w swoich rozstrzygnięciach w sferę prawodawczą i sądowniczą. To zaś zmuszało jej członków do umiejętnego poruszania się w ramach nadanych Radzie kompetencji, a nierzadko balansowania na cienkiej granicy między thumaczeniem a stanowieniem lub stosowaniem prawa. Wydaje się, że z zadania tego Rada wywiązała się co najmniej poprawnie. Jego realizację można ocenić stosunkowo wysoko, co znacznie powinno poprawić ogólny wizerunek samej Rady. Dlatego biorąc za kryterium jej aktywność w przedmiocie prowadzonej wykładni prawa, warto przynajmniej po części zrewidować dotychczas głoszone na jej temat poglądy. Przez pryzmat wydawanych rezolucji Rada Nieustająca jawi się bowiem jako kompetentny, rzetelny i sprawnie działający nowoczesny organ rządowy.

\section{INTERPRETATIVE RESOLUTIONS OF THE PERMANENT COUNCIL}

\section{Summary}

One of the most important powers of the Permanent Council that functioned in the years 1775-1789 in Poland was the interpretation of the law in force. The Council issued interpretative resolutions based on the drafts prepared by the Department of Justice, and those resolutions were subsequently approved at the Council's plenary sessions. Minutes of the Permanent Council's sessions that have been preserved to these days were the subject of a study which subsequently allowed to identify the entities which petitioned for the interpretation of an unclear provision, the main reasons of doubts in the construction of law, and the main issues or problems that needed to be clarified. The knowledge gained from this study sheds new light on the performance of the Permanent Council which was the first central body of executive power operating in the Polish territory.

\section{RÉSOLUTIONS D'INTERPRÉTATION DU CONSEIL PERMANENT}

\section{Résumé}

L'un des principaux pouvoirs du Conseil Permanent fonctionnant dans les années 1775-1789 était le fait d'interpréter la loi en vigueur. La mission est réalisée sous forme de résolutions dont le projet est préparé au Département de la Justice du Conseil, et est validé lors des séances plénières. La documentation conservée jusqu'à nos 
jours, soit les procès-verbaux du Conseil Permanent, a permis de faire une analyse et de parvenir aux conclusions relatives aux individus demandeurs d'une interprétation des dispositions incompréhensibles (raisons principales des doutes d'interprétation survenus) et à la matière principale qui constitue, le plus souvent, l'objet des questions envoyées au Conseil. Le savoir acquis suite à ces analyses permet d'évaluer, sous une nouvelle lumière, l'activité du Conseil Permanent, le premier organe central du pouvoir exécutif sur le territoire polonais. 